\title{
Las 'Declamaçiones' de Séneca traducidas por Alonso de Cartagena: edición y estudio*
}

\author{
Jorge FERNÁNDEZ LÓPEZ \\ Universidad de La Rioja \\ jorge.fernandez@unirioja.es
}

Recibido: 4 de junio de 2013

Aceptado: 20 de octubre de 2013

\begin{abstract}
RESUMEN
Este trabajo consiste en la edición crítica de las versiones romances de diez Controversias pertenecientes a la colección reunida por Séneca el Viejo, que Alonso de Cartagena (1385-1456) realizó, por encargo del rey Juan II de Castilla, a principios de la década de 1430. El texto, transmitido por cerca de una treintena de manuscritos e impresos, aparece siempre integrado dentro de unos llamados Libros de Sé$n e c a$, colección de obras en la que se fue incluyendo un número creciente de escritos del autor romano o a él apócrifamente atribuidos (como es este caso). A la edición del texto precede un estudio introductorio que da cuenta del origen y transmisión de esta obra, que explica los criterios de edición y que presenta los rasgos generales de la labor realizada por el traductor.
\end{abstract}

Palabras clave: Alonso de Cartagena. Séneca el Viejo. Controversiae.

FERnÁndez LóPEz, J., «Las 'Declamaçiones' de Séneca traducidas por Alonso de Cartagena: edición y estudio», Cuad. Fil. Clás. Estud. Lat. 33.2 (2013) 329-380.

\section{Seneca's 'Declamations' translated by Alonso de Cartagena: edition and study}

\begin{abstract}
This paper presents the critical edition of ten among Seneca's Controversies as translated into Spanish by bishop and diplomat Alonso de Cartagena (1385-1456). King John II of Castile commissioned the translation in the early $1430 \mathrm{~s}$, and some thirty manuscripts and printed editions have transmitted it. The text is always included in the wider Libros de Séneca (Books of Seneca), a collection of works by or apocryphally attributed to the Roman author. The edition of the text of the translated Controversies is preceded by an introductory study that accounts for the origin and transmission of the work and that also presents the general traits of the translator's task.
\end{abstract}

Keywords: Alonso de Cartagena. Seneca the Elder. Controversiae.

FERNÁNDEZ LóPEZ, J., «Seneca's 'Declamations' translated by Alonso of Cartagena: ediWRn [Doftstudy», Cuad. Fil. Clás. Estud. Lat. 33.2 (2013) 329-380.

\footnotetext{
* Agradezco las valiosas sugerencias que para la mejora de este trabajo he recibido de los profesores Tomás González Rolán (Universidad Complutense de Madrid) y María Morrás Ruiz-Falcó (Universitat Pompeu Fabra de Barcelona).
} 
Sumario 1. Séneca en la Castilla del siglo XV: las traducciones de Alonso de Cartagena. 2. Las Controversias de Séneca y las Declamaciones de Cartagena. 3. Los manuscritos y nuestra edición de las Declamaciones. 4. El texto latino. 5. La Traducción. 6. Referencias bibliográficas.

\section{SÉNECA EN LA CASTILLA DEL SIGLO XV: LAS TRADUCCIONES DE ALONSO DE CARTAGENA}

Pocos autores del mundo antiguo recibieron tanta atención en la Castilla del siglo XV como Séneca, nombre en el que todavía por aquella época se fundían el filósofo Lucio Anneo Séneca y su homónimo padre, y bajo cuya prestigiosa autoría circulaba también un buen número de obras erróneamente a él atribuidas (Blüher 1983, pp.113-222). Muestra de este interés es la intensa labor de traducción al castellano de que fue objeto la obra debida o atribuida a este autor, y que se desarrolló en torno a dos círculos, uno auspiciado por el rey Juan II y otro, de menor relevancia en lo que a Séneca se refiere, impulsado por el Marqués de Santillana y en el que el papel principal lo desempeñó Pedro Díaz de Toledo (que tradujo unos apócrifos pero exitosísimos Prouerbia Senecae: Blüher 1983, pp.148-150).

Quien con más ahínco se dedicó a traducir la obra de Séneca fue, sin embargo, Alonso de Cartagena, figura señera de la cultura, la diplomacia y la Iglesia castellanas de la época, que ya había puesto en vernáculo varias obras de Cicerón (Mascagna 1969, Morrás 1996 y Baldissera 2003) y que a instancias del rey Juan II fue romanceando hasta una docena de los escritos que por entonces circulaban bajo el nombre de Séneca (Morrás 2002, pp.93-127). Como dijo Blüher (1983, p.145) hace más de cuarenta años, «la significación de Alonso de Cartagena para la propagación de las obras de Séneca en España en el siglo XV fue extraordinaria». En efecto, como resultado del encargo explícito y, según parece, apremiante en ocasiones, del monarca castellano, Alonso de Cartagena tradujo al romance entre los años 1431 y 1443 un puñado de obras escritas por Séneca o a él atribuidas (Blüher 1983, pp.141-142; Round 2002, pp.129-132).

Entre ellas se encuentran, en primer lugar, varios textos 'auténticos': el De clementia, diálogos como De prouidentia, De uita beata y De constantia sapientis (aunque titulados erróneamente en algún caso) o una de las Epistulae ad Lucillium (la extensa número 88, dedicada a las artes liberales). Cartagena tradujo, además, otras composiciones, como el llamado Libro de las quatro virtudes o las Declamaçiones que aquí nos ocupan, y que corresponden, respectivamente, a la Formula honestae uitae de Martín de Braga y a varias de las Controuersiae de Séneca el Viejo. En tercer lugar, Cartagena redactó versiones castellanas, completas o parciales, de diversas antologías que circulaban bajo el nombre de Séneca: unos Amonestamientos e doctrinas (que incluían sólo algunos pasajes de Séneca junto con citas de otros numerosos autores), unos Dichos de Séneca en el fecho de la cavallería (extractos en realidad del De re militari de Vegecio: González Rolán - Saquero Suárez-Somonte 1988) y una Copilaçión, que como veremos en seguida es la que aquí más nos interesa, y que consiste en la traducción de una selección de los fragmentos de Séneca que el domi- 
nico Luca Mannelli reunió a mediados del siglo XIV y que circuló con el título de Tabulatio et expositio Senecae (sobre la que véase Kaepelli 1948 y Olivetto 2011, pp.17-39). El cuadro general del conjunto, que Round (2002, pp.127-128) recapitula con gran concisión y claridad, sería el siguiente:

A. Obras auténticas de Séneca (con sus títulos correctos):

Libro primero de la providençia de Dios (De prouidentia I)

Libro primero de la clemençia (De clementia I)

Libro segundo de la clemençia (De clementia II)

B. Obras auténticas de Séneca (con títulos incorrectos):

Libro segundo de la providençia de Dios (De constantia sapientis)

Libro de la vida bienaventurada (De uita beata + De otio sapientis)

Libro de las siete artes liberales (Epistulae morales 88)

C. Obras 'pseudo-senecanas'

Libro de los remedios contra la fortuna (De remediis fortuitorum, atr. a Séneca) Libro de las quatro virtudes (Martín de Braga, Formula honestae uitae) Amonestamientos e doctrinas (De legalibus institutis, colección de sentencias) Dichos de Séneca en el fecho de la cavallería (extractos de Vegecio, De re militari)

D. Obras relacionadas con la Tabulatio de Mannelli

Copilaçión (extensa selección de fragmentos de Mannelli)

Libro de las declamaçiones (extractos de Séneca el Viejo, Controuersiae)

Títolo de la amistança e del amigo (antología parecida a la Copilaçión)

'Las tres hermanas vírgenes' (paráfrasis de De beneficiis 1.3)

Pues bien, esta colección de escritos 'de Séneca' romanceados fue gestándose, como ya hemos señalado, a lo largo de una docena de años, y el interés que hacia el conjunto y sus partes mostraron los lectores, copistas y propietarios de los códices en los que se difundió fue, lógicamente, variable. El resultado de ambos factores (estadios diversos y selección de obras) es que la cuarentena larga de testimonios que nos transmite estas obras presenta una enorme variedad de aspectos: cada códice incluye unas obras pero excluye otras, y el orden de las mismas en su interior está también sujeto a variaciones.

Esta disparidad en los contenidos de los códices, unida a su elevado número, ha disuadido más de una vez a los estudiosos de acometer una edición íntegra de estos valiosos textos, aunque una selección de algunas de estas traducciones (De uita beata, De prouidentia, la Epístola 88, la antología conocida como Amonestamientos e dotrinas y la Copilaçión que nos ocupa) fue impresa por primera vez con el título Cinco libros de Séneca (Sevilla, Meinardo Ungut y Estanislao Polono, 1491), y reimpresa en varias ocasiones posteriores.

Contamos sin embargo con al menos dos intentos casi simultáneos, a cargo de M. Morrás (Morrás y López Casas 2001, cuyo contenido luego se incluye en Morrás 
2002) y N.G. Round (2002), de introducir cierto orden en estas decenas de manuscritos. Ambas propuestas fueron elaboradas, según explican sus autores, a partir de una denominada 'recensión externa', esto es, basada no en la posible filiación textual de los propios testimonios transmitidos sino en el contenido y ordenación interna de los manuscritos (Orduna 1983 y 1991 y Olivetto 2011 a, explícitamente centrada en estos Libros de Séneca), y coinciden en lo fundamental de sus conclusiones en lo que se refiere a la agrupación de los manuscritos en 'familias' (Morrás propone tres) o 'tipos' (Round propone siete), aunque discrepan en la precedencia genealógica que otorgan a los distintos grupos de testimonios. Volveremos más adelante sobre este asunto, cuando tratemos de los manuscritos en los que hemos basado nuestra edición.

\section{LAS CONTROVERSIAS DE SÉNECA Y LAS DECLAMAÇIONES DE CARTAGENA}

La obra 'de Séneca' de cuya traducción aquí nos ocupamos lleva como título completo Controuersiarum sententiae, diuisiones, colores, y constituye en su forma original una selección de fragmentos de controuersiae pronunciadas por declamadores famosos de los años en los que vivió su recopilador, Séneca el Viejo (aproximadamente, 54 a. C. - 39 d. C.). La controuersia, como es sabido, era un ejercicio declamatorio que comenzó a tomar auge precisamente a comienzos del s. I d. C., y que consistía en un discurso del género forense compuesto para una situación ficticia, propuesta a menudo en términos imaginativos y un tanto retorcidos (lo que causó no pocas críticas en la época y en la posteridad). Séneca ordenó su antología en diez libros, cada uno de los cuales contenía entre seis y nueve temas y estaba precedido de un prefacio en el que, además de tratar otros asuntos, se presentaba sumariamente a los declamadores cuyas citas se reproducían después. La estructura en la que Séneca dispone su material es sistemáticamente la misma: (a) en primer lugar, la ley (casi siempre ficticia) alrededor de la que gira el supuesto juicio; (b) en segundo lugar, la exposición sucinta del caso acaecido y la formulación de la acusación concreta por la que se enfrentan las partes; (c) en tercer lugar, las sententiae, esto es, frases más o menos ingeniosas, lapidarias y 'sentenciosas' que distintos declamadores incluyeron en sus orationes sobre el tema, agrupadas según la postura, a favor o en contra, adoptada; (d) en cuarto lugar, las diuisiones, o posibles enfoques 'técnicos' desde los que abordar el tratamiento del caso; (e) $\mathrm{y}$, por último, los colores o alardes argumentativos cuya formulación servía para apuntalar la propia posición, que acudían a menudo a giros inesperados.

Según recapitula M. Winterbottom (1974, pp.xix-xx) en la introducción a su edición en la Loeb Classical Library, estas Controuersiae nos han llegado a través de dos tradiciones manuscritas claramente separadas: (a) la primera de ellas nos proporciona el texto en la extensión completa que ahora tenemos (libros 1, 2, 7, 9 y 10 más los prefacios a los libros 7, 9 y 10); (b) la segunda abarca los 10 libros por entero y es la única fuente que nos transmite los títulos de cada controuersia; contiene además los prefacios completos de los libros 1, 2, 3, 4, 7 y 10 que no trae la otra rama, pero, y esto es lo fundamental, sólo recoge algunos pasajes de cada uno de los temas. La labor 
excerptoria fue, según palabras de Winterbottom (1974, p.xix), 'salvaje': se eligen casi siempre exclusivamente pasajes del apartado de las sententiae, se omiten las atribuciones a los distintos declamadores y el excerptor se ha tomado con el texto original, según puede comprobarse en aquellos libros de los que hemos conservado las dos versiones, las libertades que ha considerado necesarias para mejorar rítmicamente algunas de las sententiae o para que la inteligibilidad del nuevo fragmento separado de su contexto no se resintiese, alterando sintaxis, introduciendo sujetos u objetos que no estaban en el original, etc.

De estas dos tradiciones, la que disfrutó de difusión más amplia durante toda la Edad Media fue, como puede esperarse, la excerptoria: a ella acudió el difundidísimo Florilegium Gallicum (Muñoz Jiménez, 2004) o el comentarista N. de Trevet (cuyas anotaciones a las Controuersiae de Séneca, conservadas en un buen número de manuscritos, aún permanecen inéditas y casi sin estudiar). Así, pues, el texto de las Controuersiae al que se acercaron la mayoría de lectores, Cartagena incluido, fue, en realidad, una antología de una parte -las sententiae- de la antología original. En esta versión abreviada, por lo tanto, no hay ya separación entre lo que corresponde a un declamador y a otro ni indicación alguna al respecto, y tras la exposición de la ley y del caso lo que viene son dos series de sententiae que carecen de conexión estrecha entre sí, pero que tratan sobre el mismo caso y adoptan la misma postura, a favor o en contra, de la acusación propuesta. Por ello se interpretó mayoritariamente que lo que Séneca ofrecía a sus lectores eran discursos breves pero enteros, puestos en boca de un solo abogado, y no una selección de frases provenientes de discursos y autores distintos.

De las 74 controuersiae originales que reunió Séneca y que en versión 'extractada' transmite esta tradición, Alonso de Cartagena traduce diez (Blüher, y quienes le citan, hablan de once, pero eso es porque incluyen en su cómputo un breve fragmento de III 8 que luego se repite en la versión completa de esta misma controuersia, la última que traduce Cartagena). En el orden de aparición en la obra original (no el de la traducción) son las siguientes: I 5 («Raptor duarum»), II 2 («Iusiurandum mariti et uxoris»), III 8 («Olynthius pater reus concursus»), III 9 («Crux serui uenenum domino negantis»), IV 4 («Armis sepulchri uictor»), V 1 («Laqueus incisus»), V 5 («Domus cum arbore exusta»), V 7 («Non recepti ab imperatore»), VI 6 («Adultera uenefica») y VIII 2 («Phidias amissis manibus»). El proceso, sin embargo, no fue resultado de un único empeño constante y puede reconstruirse en los pasos que describimos a continuación.

Entre las obras 'de Séneca' que el rey Juan II encarga traducir a Alonso de Cartagena se encuentra en lugar destacado una considerablemente peculiar: la Tabulatio et expositio Senecae o Compilatio Senecae de Luca Mannelli (descrita detalladamente en Kaepelli 1948), que se convierte en lo que Cartagena llama Copilaçión. Esta obra, que había sido encomendada hacia 1340 por el papa Clemente VI al dominico Luca Mannelli, a la sazón en la curia de Avignon, consistía, como reza su título, en una Tabulatio y una Expositio de las obras de Séneca. Esto es, se trataba en primer lugar de una antología de citas de Séneca procedentes de obras tanto auténticas como apócrifas: Kaepelli (1948, pp.262-264) reproduce el prólogo de Mannelli a partir del manuscrito Parisinus Latinus 8714, en el que este dominico del siglo XIV da cuenta de la nómina de obras 'de Séneca' que ha tenido a su disposición. Entre ellas se cuentan, por supuesto, 
las Controuersiae, llamadas aquí Declamationes, pero la selección de citas se ha realizado (respetamos los criterios de transcripción utilizados por Kaepelli),

super omnes libros Senece quos habere potui, uidelicet super epistolas ipsius Senece ad Paulum, super XXII libros epistolarum ad Lucillium, super librum de beata uita, super duos libros de dei prouidentia, super tres libros de ira, super VII libros de beneficiis, super VI libros de questionibus naturalibus, super IX libros declamacionum, super duos libros de clementia, super librum de consolatione ad Martiam, super librum de consolatione ad Polibium, super librum de consolatione ad Helbiam, super librum de moribus, super librum de quatuor uirtutibus qui alias dicitur et intitulatur de copia uerborum, super librum de studiis liberalibus, super librum de remediis fortuitorum, super X tragedias et super librum de ludo Claudii. De libro autem prouerbiorum et libro de paupertate nichil omnino accepi, quia isti duo libri sunt excerpti de dictis eius de uerbo ad uerbum, ut patet diligenter intuenti. De libro uero contra superstitiones, quem beatus Augustinus pluries allegat, et maxime VI de ciuitate dei, nichil sumpsi, quia ipsum habere non potui.

Las citas así extractadas se agrupan bajo lemas temáticos ordenados alfabéticamente, el primero de los cuales es 'abstinentia'. Esta Tabulatio se dispone a dos columnas en cada página de los manuscritos conservados, con los lemas marcados en rojo, y a su alrededor se agolpa en letra de cuerpo menor la Expositio o comentario de los pasajes reproducidos, en la que se persigue iluminar los textos de Séneca aportados con el recurso a otros autores, paganos y cristianos, a los que, admite Mannelli, no trata de manera absolutamente rigurosa (Kaepelli 1948, p.264). Según deduce Kaepelli con todo fundamento, la obra circuló en dos volúmenes (que abarcarían los lemas encabezados por las letras A-I y L-V respectivamente), pero sólo hemos conservado unos pocos ejemplares del primero de ellos: Kaepelli cita en concreto tres manuscritos, depositados en París (el Parisinus latinus 8714 cuyo prólogo edita), Madrid (Biblioteca de Palacio 149, que hoy es Biblioteca Universitaria de Salamanca 2638), y Cracovia (Bibl. Jagellon. CC. VIII. 2). Toselli (2007), en el resumen que puede consultarse de su estudio, señala los mismos tres testimonios, con los que relaciona otros dos manuscritos: Parisinus latinus 8715, una suerte de editio minor de la Tabulatio, y Vaticanus Borghese 10, florilegio senecano más antiguo (descripción detallada del salmantino en Lilao - Castrillo 2002, pp.1008-1009; Olivetto 2011, pp.468-473).

La extensión de esta Tabulatio, el carácter heterogéneo de las citas en ella contenidas y la facilidad que ofrece cualquier antología de este tipo para efectuar sobre ella una nueva selección hizo que la Copilaçión de Cartagena acabara consistiendo en la traducción de un número de pasajes muy inferior al del original, elegidos además conforme a los intereses del monarca que supervisó la elaboración de esta versión. En efecto, dice el propio Alonso de Cartagena $\left(1491\right.$, fol. $\left.[\mathrm{r} v \mathrm{vj}]^{\mathrm{v}}\right)$ al final de la obra:

Aquí se acaba la una copilaçión de algunos dichos de Séneca sacados de vuestra grand copilaçión de sus dichos e doctrinas. Fue hecha e fueron tornados de latín en lenguaje castellano por mandado del muy alto prínçipe, muy poderoso rey e señor el rey don Juan. E no van situados por ordenaçión, por quanto fueron trasladados acaso segund que a cada uno en leyendo le bien paresçió. E añadiéronle las glosas e algunas adiçiones en los lugares donde el dicho señor rey mandó. 
Las citas así acumuladas acaban presentándose al lector con un aspecto un tanto curioso, ya que los textos 'de Séneca' que ofrece la Copilaçión de Cartagena van precedidos sistemáticamente por: (a) un título que hace referencia al lema bajo el que Mannelli incluye el fragmento en cuestión, para lo que Cartagena emplea casi siempre el término 'tractado'; (b) una breve explicación del asunto del que se trata y del ámbito de aplicación moral del mismo; (c) la referencia a la obra original de la que se extrae el pasaje. Un ejemplo de ello, con texto del Agamenón (284-288), es el siguiente (Cartagena 1491, fol. $[\mathrm{m} \mathrm{v}]^{\mathrm{r}-\mathrm{v}}$ ):

En el tractado de la fe e lealtad.

Que no se halla lealtad en las casas de los reyes, e que la lealtad que por preçio es conprada por preçio se vende.

En la tragedia octava:

«CLITEMESTRA- No sabe mis malefiçios sino servidor leal.

EGISTRO- Nunca entra lealtad por el unbral de la puerta del rey.

CLITEMESTRA-Con mis riquezas haré que por preçio me guarden la fe.

EGISTRO- La lealtad por preçio ganada, con preçio se vende.»

Los pasajes de Séneca, como indica Cartagena en las líneas citadas con las que cierra su Copilaçión, se ven complementados por un buen número de glosas marginales. Estas glosas, que proceden también del original de Mannelli, a menudo ocupan más espacio que el propio texto, y en su mayor parte son paráfrasis explicativas redondeadas con consideraciones morales y, en las ocasiones en que se ha considerado oportuno, con aclaraciones de realia. En la selección de Cartagena predominan las citas provenientes de las obras morales de Séneca (De prouidentia, De ira, De tranquillitate animi,...$)$, aunque de vez en cuando Cartagena o Juan II se han interesado por fragmentos de obras más 'exóticas' como las Naturales quaestiones, el apócrifo De remediis o la que aquí nos interesa: las Controuersiae de Séneca el Viejo. Así, el lector se encuentra con dos fragmentos de las Controuersiae que, por su carácter moralizante, casan bien con el resto de la obra. La primera de ellas, que gira en torno a la elocuencia 'irregular' de la que a veces están dotados los oradores profesionales (Contr. III pr., 1), es la siguiente (Cartagena 1491, fol. [n vi] ${ }^{\mathrm{v}}-[\mathrm{n} v \mathrm{vij}]^{\mathrm{v}}$ ):

En el tratado de la fama.

Dize Séneca que oyó a muchos de los onbres bien hablantes proponer muy bien en el juyzio e que no hablan bien en las otras cosas, e que muchos han fama de hablar bien que no hablan tan bien como han la fama.

En el prólogo del libro terçero de las Declamaçiones:

«Conosçí a algunos varones muy polidos en hablar que no respondía en ellos el hecho a la fama, e quando proponían en juyzio maravíllanse todos cómo dezían tan bien, e quando hablavan en otros hechos fallesçíales el yngenio, de lo qual me maravillé, pero ove por çierto que acaesçió a muchos».

Unas páginas antes Cartagena (1491, fol. $\mathrm{m}$ ii ${ }^{\mathrm{r}-\mathrm{v}}$ ) se había detenido en otra (Contr. I 2,10; la segunda se atribuye erróneamente a esta obra), centrada en el recurrente asunto de la pudicitia femenina: 
En el libro primero de las Declamaçiones, en la declamaçión segunda: «Non es asaz casta aquella de cuya castidad se dubda».

En esa mesma declamaçión: «muchas vezes son castas las que son feas de cara, no porque fallesçe la voluntad, mas porque fallesçe quien las sigua».

Pues bien, como en otros casos, la traducción de fragmentos de algunas obras despertó en Cartagena o en el monarca que supervisaba y estimulaba la labor de romanceamiento el interés por la obra completa de la que procedían las citas, y así Cartagena se animó a redactar versiones castellanas de tres Declamationes (título bajo el que circulaban las Controuersiae) 'completas' (siempre dentro de la tradición 'excerptoria' que ya hemos mencionado; se trata de I 5, VIII 2 y III 9), más un breve fragmento de otra (unas líneas de III 8, que tradujo en su integridad posteriormente). Estos textos quedaron incluidos hacia el final de la Copilaçión, aunque en una situación un tanto anómala, ya que cada uno de ellos presenta una extensión algo mayor que las pocas líneas del fragmento 'estándar' de esta antología. Que Cartagena las consideraba aún parte de la Copilaçión lo muestra que las tres están introducidas con el título localizador habitual en esta obra, «En el tractado de...» (en concreto, «En el tratado del forçador e del robo», I 5; «En el tratado del sacrilegio», VIII 2; y «En el tratado de la servidumbre del siervo», III 9).

Cartagena terminó su Copilaçión, como convincentemente demuestra Round (2002, p.130) y Olivetto confirma (2011, p.69), hacia el verano de 1431. Poco después tradujo otras siete Declamaçiones, que, ya sí, aparecen como obra independiente, con su propio título y sin los encabezamientos individuales que aluden a supuestos 'tratados'. Así, en varios de los manuscritos, la 'segunda serie' de siete Declamaçiones viene introducida por título propio: por ejemplo, en el ms. 6962 de la Biblioteca Nacional de Madrid se ha reservado un folio entero (fol. CXXIIv) a la portada de esta 'obra' de Séneca, cuyo vuelto se ha dejado en blanco y en cuyo recto figura únicamente la rúbrica «Aquí en este quaderno son escriptas algunas declamaçiones que fueron sacadas de diuersos lugares del original de las declamaçiones». En los manuscritos en los que, como veremos, las Declamaçiones siguen inmediatamente a la Copilaçión, el conjunto de las diez traducciones se ve interrumpido únicamente por unos pocos folios que contienen el final de la Copilaçión. Otros manuscritos, sin embargo, en los que se sometió a otra reordenación el conjunto de las obras de Séneca, traen las Declamaçiones mucho antes de la Copilaçión, con lo que los dos grupos de siete y tres Controuersiae están separados por varias decenas de folios. Como podría esperarse, en la reordenación definitiva de las traducciones de Cartagena se reunieron los diez textos, que quedaron ya como obra independiente y en el orden siguiente (omitido el breve fragmento de III 8): I 5, VIII 2, III 9, III 8, IV 4, V 1, V 7, II 2, V 5, VI 6, III 8.

¿Cómo explicar la presencia de estos textos en compañía de otros cuyo carácter predominantemente moralizante no comparten? Uno de los motivos que sin duda hubo de provocar el interés del traductor y/o del monarca fue el contenido narrativo de los casos en torno a los que giran las Controuersiae, cuyo planteamiento constituye, tal y como está formulado, un breve relato que no es difícil relacionar con varias formas de la literatura sapiencial de la época. Veamos tan solo dos ejemplos. El primero es el de V 1 y su suicida frustrado, que tiene puntos en común con un breve poema de 
Ausonio celebrado modernamente como micro-relato (Aus.Epigr.19.14 Evelyn-White, «De eo qui thesaurum repperit cum se laqueo uellet suspendere», procedente a su vez de Anth.Gr.9.44, y que presenta el caso de un hombre que buscando dónde ahorcarse encontró un tesoro):

Un ombre andando por la mar ovo tormenta tanto que quebró el navío e él salió a nado desnudo; e después quemósele la casa e muriéronsele la muger e tres fijos que tenía. E él con la grand tristeza colgóse de un árbol por morir, e estando así colgándose acaesçió de pasar un ombre por ende e cortóle la soga e escapó. E así librado acusa al que le cortó la soga desto como de malefiçio.

El otro es el de VI 6, en el que se nos retrata la crudelis adultera habitual de la declamación antigua y que, además del adulterio entre los futuros suegra y yerno, contiene los ingredientes morbosos del envenenamiento y del interrogatorio mediante tortura:

Uno tenía una muger e della una fija de hedad para casar, e dixo a su muger que quería casarla con un mançebo que le nombró. E la muger en oyéndolo dixo luego de priesa estas palabras: 'ante morrá que con él case'. Acaesçió que la moça murió ante de las bodas, e en su muerte ovo algunas señales por donde se presumió que moría de yervas. El padre por saber la verdad atormentó a una sierva suya e preguntóle deste fecho. E la sierva dixo que non sabía cosa alguna de las yervas, mas que sabía que su muger cometía adulterio con aquel mançebo con quien el padre quería casar su fija. Agora este ombre acusa a su muger de las yervas e del adulterio.

No es de extrañar que historias de este cariz enterradas entre las obras del moralísimo Séneca despertaran la curiosidad de Juan II o de Alonso de Cartagena, y que alguno de los dos se animase a tomar la decisión de incluir al menos unas cuantas en un conjunto en el que el peso de lo didáctico era abrumador. Pero a la fuerza de lo narrativo, a la afinidad con apólogos y similares y a la universal atracción del ser humano por lo morboso en general hay que añadir otro factor que probablemente facilitó que estas Declamaçiones acabaran formando parte de los Libros de Séneca: se trata de su vertiente jurídica, por ficticios que sean los términos en los que esta se presenta. No olvidemos que Alonso de Cartagena fue un destacado jurista de su tiempo, y en el mundo del derecho de la época había un 'género legal' que guardaba considerables semejanzas, al menos formales, con estas Controuersiae: el de los 'Fueros' y 'fazañas'. En efecto, como ha señalado F. Gómez Redondo (1998, pp.89-94), las 'fazañas' nos transmiten una información valiosísima sobre la vida cotidiana medieval, pero lo que aquí nos interesa es más su aspecto formal, dado que constituían relatos de casos jurídicos que pasaban por realmente acaecidos y que se insertaban, a modo de ilustración, en la redacción de los fueros de diversas ciudades. Los textos así resultantes, en los que al tenor de la ley le acompaña el caso en el que se aplica, no pudieron dejar de recordar al eximio jurista que fue Cartagena el contexto de los discursos que él atribuía a Séneca. Un ejemplo de ello nos lo proporcionan los paralelos entre una 'fazaña' contenida en el Fuero de Sepúlveda, que reproduce Gómez Redondo, y la exposición del primero de los casos que traduce Cartagena. En el Fuero de dicha ciudad segoviana encontramos la narración siguiente (Gómez Redondo 1998, p.89): 
Ésta es façaña de Fuero de Castiella: Que de un ome de Castro de Urdiales, querellábase una moça, que la forçara, e que ·l' avía quebrantado toda sua natura con la mano, era apreciada como es de derecho. E judgaron que·l' cortasen la mano, e después que $\cdot 1$ ' enforcasen.

La Controuersia I 5 de Séneca trata también el tema de una doncella forzada, y el texto que se dedica a la 'información preliminar' de ley y caso acontecido es el siguiente:

En una çibdad avía una ley que dezía así: 'La muger forçada puede escoger una de dos cosas, o que maten al forçador o que gelo den por marido sin que ella le dé dote alguno'. El caso acaesçió desta manera: uno forçó en una noche dos mugeres; la una pide que le maten, la otra demanda que gelo den por marido.

Sea como fuere, por un interés más o menos vago del traductor o del monarca, por el contenido ficcional o morboso de las mismas, por su aire de familiaridad con textos jurídicos de la época (Fernández López, e. p.), estas diez Controuersiae de Séneca pasaron a formar parte de la compleja tradición de los Libros de Séneca, en la que entramos inmediatamente.

\section{LOS MANUSCRITOS Y NUESTRA EDICIÓN DE LAS DECLAMAÇIONES}

Como hemos señalado, los Libros de Séneca traducidos por Cartagena disfrutaron de una enorme popularidad durante todo el siglo XV. Prueba de ello son los numerosos testimonios manuscritos en los que aún los conservamos, resto material de la que fue sin duda una muy amplia difusión. En el capítulo que M. Morrás dedica a Alonso de Cartagena en el Diccionario filológico de literatura medieval española esta estudiosa proporciona un listado de hasta 41 códices que transmiten, en una u otra combinación, estas versiones de obras senecanas (Morrás 2002, pp.98-99); dicho listado, con ligeras ampliaciones y puntualizaciones, puede encontrarse también en la reciente edición de Olivetto (2011, pp.70-92) de un extenso capítulo de esta Copilaçión de Cartagena. De todos ellos son varios los códices que no incluyen las Declamaçiones, con lo que el número total quedaría reducido a algo más de una veintena:

- Aix-en-Provence, Biblioteca Méjanes 1524;

- Lisboa, Biblioteca de Ajuda, ms. 46-VIII-1;

- Madrid, Biblioteca Nacional, 817, 6765, 6962, 8188, 8241, 8830, 10139, 10155, 12172, 17798 y 17803;

- Madrid, Real Biblioteca, mss. II/1842, II/1878 y II/3072;

- Salamanca, Biblioteca Universitaria, mss. 201, 1813 y 2197;

- San Lorenzo de El Escorial, Biblioteca del real Monasterio, N.II.6, T.III.3, T.III.4, T.III.5 y T.III.6;

- Santander, Biblioteca Menéndez y Pelayo, ms. M-97;

- Valladolid, Biblioteca Universitaria de Santa Cruz, ms. 338. 
Según decíamos, Morrás propone una distribución de estos códices en tres 'familias', asumida también por Ruiz García (2004) y Olivetto (2011, pp.86-92), a las que distinguiría el progresivo aumento de tamaño y grado de organización del conjunto de obras; Round por su parte, propone hasta siete 'tipos' distintos y, aunque coincide a grandes rasgos con la agrupación de Morrás, algunas de sus conclusiones son distintas. Vayamos por partes.

El primer 'tipo' que propone Round, $\alpha$, se caracterizaría por contener diez de las obras, encabezadas por el libro I de De prouidentia, así como por su estrecha vinculación con los códices que tenían como destinatario directo al monarca que encargó las traducciones. Round (2002, pp.132-134) incluye en este grupo cinco manuscritos, los fundamentales de los cuales serían Biblioteca Nacional de Madrid 6765 (descripción en Olivetto, pp.269-274) y Biblioteca Universitaria de Salamanca 201 (Olivetto 2011, pp.403-409), por ser los únicos que transmiten las diez obras (en los otros tres faltan unas u otras obras, y ninguno de ellos incluye las Declamaçiones que aquí nos ocupan). Para Morrás (2002, p.110), ambos manuscritos están relacionados entre sí y pertenecen a la misma familia, que denomina ' $\mathrm{B}$ ' y que «parece representar un estado intermedio de reorganización de la colección». Para nuestra edición hemos tenido en cuenta ambos testimonios, que hemos siglado respectivamente como $M$ y $S$.

Round propone a continuación otros tres tipos de códices que, según la que considera filiación más probable, derivarían todos del tipo a anterior. De ellos, $\beta$ sólo estaría representado por un códice (Biblioteca Nacional de Madrid 5568, que no transmite las Declamaçiones), mientras que los tipos $\gamma$ y $\delta$ presentarían cada uno una ordenación propia de las obras, y sus textos habrían estado sometidos a una intensa contaminación. Al primero de ellos, $\gamma$, pertenecerían cuatro códices (Biblioteca Nacional de Madrid 6962 y 10139, Escorial T.III.6 y Aix-en-Provence, Biblioteca Méjanes 1524), de los cuales el primero de los matritenses (6962) precedería textualmente a los demás (Olivetto 2011, pp.275-281); hemos elegido por ello también este códice para nuestra edición y lo hemos siglado como $N$. Morrás reúne tres de estos códices (deja fuera el de El Escorial, que asigna a la familia ' $C$ ') también en la familia 'B', lo que quiere decir que coincide con Round en establecer una relación directa entre la mayoría de estos testimonios y los del grupo anterior. Para nuestro texto hemos acudido también a este códice de El Escorial (al que hemos atribuido la sigla $S$ ), debido a esta divergencia entre Round y Morrás a la hora de emparentarlo con el resto de testimonios, a la consideración que le mereció a O.T. Impey (1972) en uno de los primeros estudios sobre este corpus textual y a la datación, exacta y temprana (1447), de su copia (Olivetto 2011, pp.389-394).

Del otro tipo, $\delta$, habría hasta siete códices, cinco de los cuales tienen en común contener las doce obras de este corpus y transmitir en primer lugar el De vita beata; los otros dos derivarían de la versión que transmiten los cinco anteriores. A su vez, $\delta$ habría dado lugar a un subtipo, que Round denomina $\delta \delta$ y en el que incluye tres manuscritos que aquí no consideramos por su lugar tan secundario en la transmisión del texto. Los cinco manuscritos centrales de $\delta$ son los siguientes: Biblioteca Nacional de Madrid 8188, 8830 y 17803, Escorial T.III.7 y Santa Cruz (Valladolid) 38. De ellos 
el escurialense no incluye las Declamaçiones; de los otros cuatro, tres (los dos primeros de la B. Nacional y el de Santa Cruz) son agrupados por Morrás (2002, p.110) en la que llama familia ' $C$ ', que se caracterizaría por la voluntad que se transparenta en ella «de presentar un volumen organizado de las obras de Séneca en castellano que debía abrirse, en cualquier caso, por la Vida bienaventurada». Hemos seleccionado, así, el matritense 8188 para nuestra edición y lo hemos siglado como $O$ (descripción en Olivetto 2011, pp.281-288).

Round presenta, después, otro tipo de manuscritos al que asigna la letra $\varepsilon$ y en el que agrupa cinco códices: Biblioteca Nacional de Madrid 817, 8241, 17798, Biblioteca de Palacio II/3072 y Biblioteca Nacional de Madrid 12172 (que menciona en último lugar por haber sido copiado ya entrado el siglo XVI). De ellos, todos menos Biblioteca Nacional 17998 son agrupados por Morrás (2002, p.110) en la familia 'A', constituida por testimonios «derivados en última instancia de un mismo arquetipo copiado con gran homogeneidad en una serie cuantitativamente importante de manuscritos $(\ldots) »$, y que «ha de ser tenida en cuenta para la reconstrucción crítica de las versiones de Séneca, puesto que se remonta a un subarquetipo anterior a los que hemos descrito hasta ahora, que si bien presentan una colección más completa de títulos, necesariamente han de colocarse en un lugar más bajo del stemma». Una colación selectiva de todos ellos revela que el códice de la Biblioteca de Palacio II/3072 contiene una versión más completa del texto (no aparecen en él las omisiones que encontramos en los otros), aunque es víctima de frecuentes lapsus que son fácilmente subsanables. Hemos elegido también, por ello, este códice como uno de los testimonios para nuestra edición, y le hemos asignado la sigla $P$ (descripción en Olivetto 2011, pp.360-364).

Por último, Round considera otro subtipo derivado de $\varepsilon$ al que llama $\varepsilon \varepsilon$, cuyos tres códices, igual que en el caso de $\delta \delta$, no tenemos en cuenta para nuestro texto. Sí que recurrimos, por el contrario, a la edición princeps de las cinco que se imprimieron de estos Libros de Séneca: se trata del incunable dado a la luz en Sevilla en 1491 por los impresores Meinardo Ungut y Estanislao Polono (las otras cuatro fueron: Toledo, [sucesor de Pedro Hagembach], 1510; Alcalá de Henares, Miguel de Eguía, 1530; Amberes, Juan Stelsio, 1548 y Amberes, Juan Stelsio, 1551). Todas las ediciones posteriores derivan de ésta, y tanto Round como Morrás la relacionan directamente con el último grupo de manuscritos descrito (familia 'A' para Morrás, tipo $\varepsilon$ para Round). Aunque, lógicamente, es de escaso valor para la constitución del texto, las variantes de esta edición resultan muy informativas sobre cuál fue la versión que gozó, a través de las sucesivas impresiones, de más amplia difusión, por lo que hemos incluido este testimonio en nuestra edición como $e$.

Así pues, los testimonios que hemos utilizado para nuestra edición son un total de siete, en los que se incluyen representantes de los tipos $\alpha, \gamma, \delta$ y $\varepsilon$ de la clasificación de Round (quedan excluidos $\beta$, por no incluir las Declamaçiones y $\delta \delta$ y $\varepsilon \varepsilon$ por ser 'subtipos' derivados de $\delta$ y $\varepsilon$ ) y de las tres familias propuestas por Morrás (A, B y C). Como ya hemos señalado, el conjunto de las diez Controuersiae traducidas por Cartagena estaba originalmente dividido en dos 'obras': tres de ellas (I 5, VIII 2 y III 9) formaban parte de la Copilaçión y las otras siete se presentaban como obra independiente. En el proceso de reordenación de los Libros de Séneca, esta situación dio lugar a re- 
sultados diferentes. En resumen, los manuscritos utilizados para nuestra edición son los siguientes y presentan las Declamaçiones en la disposición que se indica (la primera fila presenta la sigla con la que nombramos cada testimonio; las dos siguientes, su procedencia; la siguiente la 'familia' y el 'tipo' en los que Morrás y Round, respectivamente, incluyen el códice o edición; a continuación, lo que se puede saber sobre la fecha de copia; y por último, los folios que ocupa cada una de las Controuersiae que cada testimonio transmite):

$\begin{array}{ccccccc}M & S & N & E & O & P & e \\ \text { B. Nac. Mad } & \text { Bib. U. Sal. } & \text { B. Nac. Mad } & \text { Escorial } & \text { B. Nac. Mad } & \text { Bib. Palacio } & \text { Edición } \\ 6765 & 201 & 6962 & \text { T.III.6 } & 8188 & \text { II/3072 } & \text { Sevilla } \\ \text { B, } \alpha & \text { B, } \alpha & \text { B, } \gamma & \text { C }, \gamma & \text { C, } \delta & \text { A, } \varepsilon & \text { A, } \varepsilon \\ \text { a. julio } 1454 & ? & \text { a. julio } 1454 & 1447 & ? & \text { a. julio } 1454 & 1491\end{array}$

Contr.

\begin{tabular}{|c|c|c|c|c|c|c|c|}
\hline I 5 & $200^{\mathrm{r}}-201^{\mathrm{r}}$ & $143^{\mathrm{r}}-143^{\mathrm{v}}$ & $209^{\mathrm{v}}-211^{\mathrm{r}}$ & - & $193^{\mathrm{v}}-194^{\mathrm{v}}$ & $156^{\mathrm{v}}-157^{\mathrm{v}}$ & $r j^{v}-r i j^{r}$ \\
\hline VIII 2 & $201 v-203^{r}$ & $143^{v}-144^{v}$ & $211^{\mathrm{r}}-213^{\mathrm{r}}$ & - & $194^{\mathrm{v}}-195^{\mathrm{v}}$ & $157^{\mathrm{v}}-159^{\mathrm{r}}$ & $\mathrm{r} \mathrm{ij}^{\mathrm{r}}-\mathrm{r} \mathrm{iij}^{\mathrm{v}}$ \\
\hline III 9 & $203^{\mathrm{r}}-204^{\mathrm{v}}$ & $144^{\mathrm{v}}-145^{\mathrm{v}}$ & $213^{\mathrm{r}}-215^{\mathrm{v}}$ & - & $195^{\mathrm{v}}-197^{\mathrm{r}}$ & $159^{\mathrm{r}}-160^{\mathrm{v}}$ & $\mathrm{r}$ iij $^{\mathrm{v}}-[\mathrm{r} \mathrm{v}]^{\mathrm{r}}$ \\
\hline III 8 (frg.) & $205^{\mathrm{r}}$ & $145^{\mathrm{v}}$ & $\longrightarrow$ & $\longrightarrow$ & $197^{\mathrm{r}}$ & $\longrightarrow$ & - \\
\hline IV 4 & $205^{\mathrm{r}}-206 \mathrm{v}$ & $145^{\mathrm{v}}-146^{\mathrm{v}}$ & $123^{\mathrm{r}}-125^{\mathrm{r}}$ & $221^{\mathrm{r}}-224^{\mathrm{r}}$ & $197^{\mathrm{r}}-198^{\mathrm{v}}$ & $163^{\mathrm{r}}-164^{\mathrm{v}}$ & {$\left[\mathrm{r}\right.$ vj] ${ }^{\mathrm{v}}-\left[\mathrm{r}\right.$ viij] ${ }^{\mathrm{r}}$} \\
\hline V 1 & $206^{\mathrm{v}}-207^{\mathrm{r}}$ & $146^{\mathrm{v}}-148^{\mathrm{r}}$ & $125^{\mathrm{r}}-127^{\mathrm{v}}$ & $224^{\mathrm{r}}-227^{\mathrm{v}}$ & $198^{\mathrm{v}}-200^{\mathrm{v}}$ & $165^{\mathrm{r}}-166^{\mathrm{v}}$ & {$\left[\mathrm{r}\right.$ viij] ${ }^{\mathrm{r}}-\mathrm{s} \mathrm{j}^{\mathrm{r}}$} \\
\hline V 7 & $207^{\mathrm{r}}-208 \mathrm{v}$ & $148^{r}-149^{r}$ & $127^{\mathrm{v}}-129^{\mathrm{r}}$ & $227^{\mathrm{v}}-230^{\mathrm{r}}$ & $200^{\mathrm{v}}-201^{\mathrm{v}}$ & $166^{\mathrm{v}}-168^{\mathrm{r}}$ & $s j^{r}-s i j^{r}$ \\
\hline II 2 & $208^{v}-208$ bis $^{v}$ & $149^{r}-149^{v}$ & $129^{\mathrm{r}}-130^{\mathrm{v}}$ & $230^{r}-232^{r}$ & $201^{\mathrm{v}}-202^{\mathrm{v}}$ & $168^{\mathrm{r}}-169^{\mathrm{v}}$ & $s i j^{r}-s i{ }^{v}$ \\
\hline V 5 & $208 b^{\mathrm{v}} \mathrm{s}^{\mathrm{v}}-211^{\mathrm{v}}$ & $149^{\mathrm{v}}-151^{\mathrm{r}}$ & $130^{\mathrm{v}}-133^{\mathrm{r}}$ & $232^{\mathrm{r}}-236^{\mathrm{v}}$ & $202^{\mathrm{v}}-204^{\mathrm{v}}$ & $169^{\mathrm{v}}-171^{\mathrm{v}}$ & $\mathrm{s}$ ij $^{\mathrm{v}}-\mathrm{s}$ iiij ${ }^{\mathrm{r}}$ \\
\hline VI 6 & $211^{\mathrm{v}}-213^{\mathrm{r}}$ & $151^{\mathrm{r}}-152^{\mathrm{r}}$ & $133^{\mathrm{r}}-135^{\mathrm{r}}$ & $236^{\mathrm{v}}-239^{\mathrm{v}}$ & $204^{\mathrm{v}}-206^{\mathrm{r}}$ & $171^{\mathrm{v}}-173^{\mathrm{r}}$ & $\mathrm{s} \operatorname{iiij}^{\mathrm{r}}-[\mathrm{s} \text { v }]^{\mathrm{r}}$ \\
\hline III 8 & - & - & $135^{\mathrm{r}}-137^{\mathrm{r}}$ & $239^{\mathrm{v}}-242^{\mathrm{r}}$ & $206^{\mathrm{r}}-207^{\mathrm{v}}$ & $173^{\mathrm{r}}-174^{\mathrm{v}}$ & {$[\mathrm{s} v]^{\mathrm{r}}-[\mathrm{s} v \mathrm{vj}]^{\mathrm{r}}$} \\
\hline
\end{tabular}

Morrás (2002, p.112), según decíamos, establece tres familias de códices sobre las que volveremos más adelante, planteándose como uno de sus objetivos fundamentales en su repaso por los manuscritos de los Libros de Séneca «el sentar las bases para reconstruir la versión primitiva y primera de los dichos Tratados de Séneca». Para ello propone, convincentemente, acudir a tres testimonios: El Escorial T.III.6, Biblioteca del Convento de San Francisco de Santiago de Compostela, sin signatura, y Madrid, Biblioteca Nacional, 5568. Ello deja 'en mal lugar' a nuestras Controversias, ya que de los tres códices sólo el escurialense, y además parcialmente, transmite el texto que nos ocupa; no obstante, como ya hemos señalado, incluimos este manuscrito en nuestra edición.

Round (2002, p.140), por su parte, se anima a proponer los tres stemmata que considera posibles tras su repaso por los manuscritos de los Libros de Séneca. Simplificando los esquemas que Round incluye en su estudio de modo que queden únicamente los siete testimonios en los que basamos nuestra edición, obtendríamos las tres propuestas siguientes, que Round presenta en orden de mayor a menor probabilidad: 


\section{STEMMA (A)}

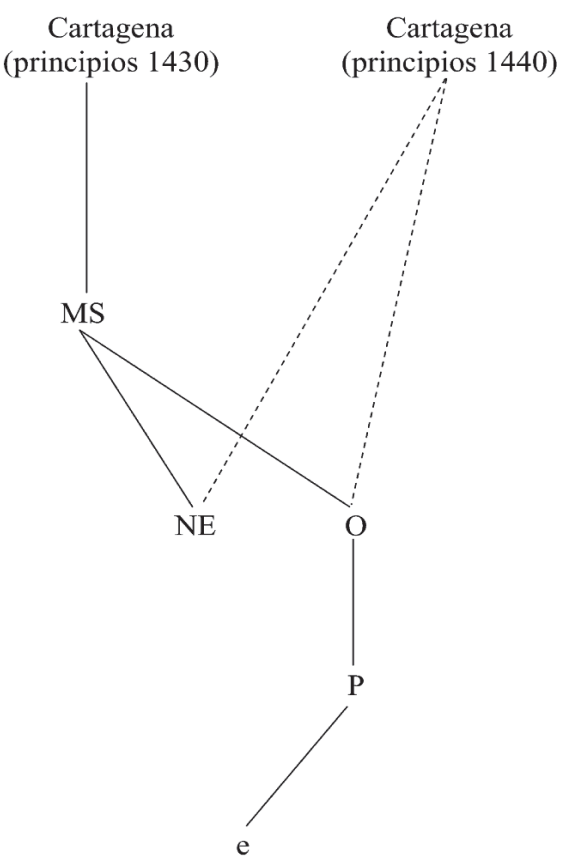

STEMMA (B)

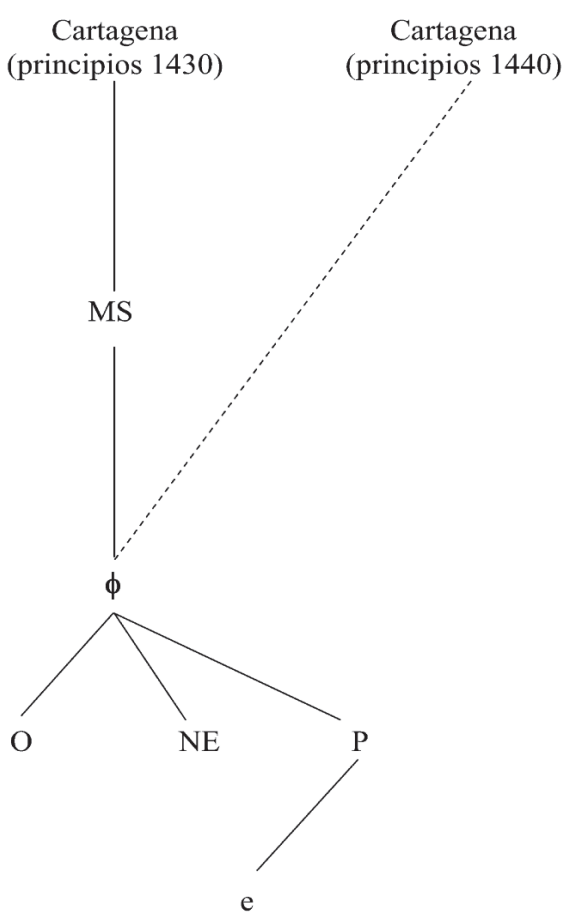

STEMMA (C)

Cartagena

(1430-1443)

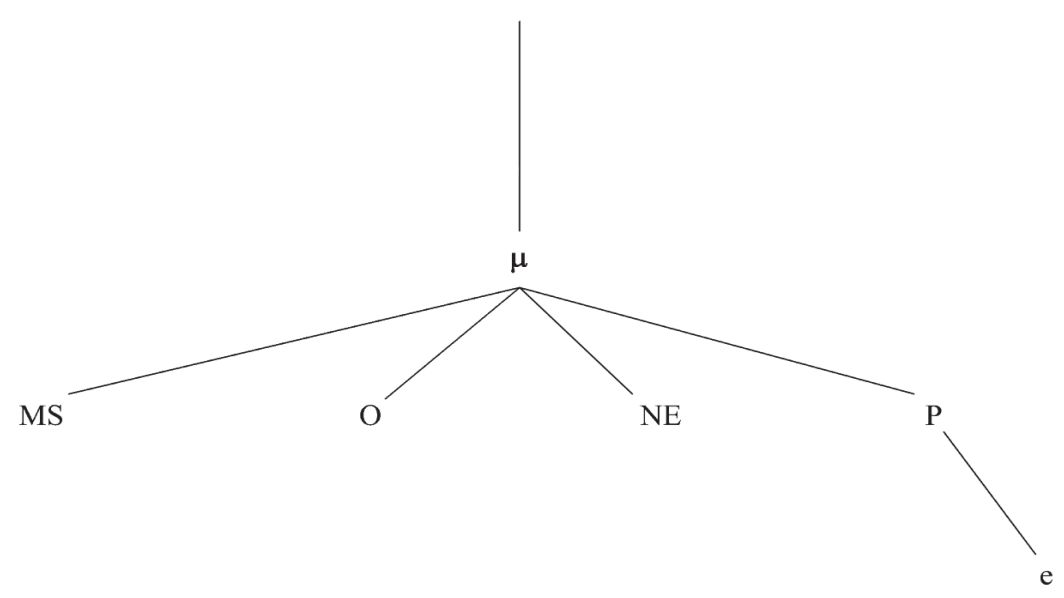


De estos tres stemmata, y a pesar de la opinión provisional de Round, los dos primeros no acaban de cuadrar con los datos que resultan de nuestro estudio de la traducción de las Controuersiae. En efecto, $M$ y $S$ presentan versiones incompletas de la obra (a ambos les falta la última controversia, III 8), y del resto de códices que Round agrupa junto con ellos en el tipo $\alpha$, ninguno transmite esta obra, por lo que difícilmente pueden estar en la base de las versiones íntegras que aparecen en otras ramas. Además, entre las lecturas que son exclusivamente compartidas por estos dos manuscritos, varias parecen apuntar a una redacción retocada con respecto a estadios anteriores (idea general que sostiene Round y que Morrás (2002, pp.112-113) atribuye a la 'familia B' a la que pertenecerían estos códices):

VIII 2, 14 lo ovo fecho e acabado $M S$ : lo ovo acabado $N O P$ : ovo acabado $e$

VIII 2, 16 contradizenlo $M S$ : contradizen NOPe

III 9,11 que lo cruçificasen o fiziesen cruçificar $M S$ : que le fiziesen cruçificar $N O P e$

III 9,31 algunas cosas e trabajos $M S$ : algunos trabajos $N O P e$

III 9, 48 morir nin bevir el $M S$ : morir el $N P e:$ morir $O$

IV 4, 23 escapar los ombres $M S$ : escapar NEOPe

$\mathrm{V} 1,14$ quebranta el navio $M S$ : quebrantan los navios $N E O P$ : quiebran los navios $e$ II 2, 19 nombradas e famosas $M S$ : famosas $N E O P e$

V 5, 4 en una çibdad avia una ley que dezia asi $M S$ : la ley dezia asi NEPe : om. $O$

V 5,16 pregunte $M S$ : fue preguntar $N E O e$ : fui a preguntar $P$

Algunas de estas variantes ("fecho e acabado", "crucificasen o fiziesen cruçificar"), como puede verse, parecen haberse originado a partir de un texto que contenía dobles traducciones. Se trata de dobletes típicos de la traducción al dictado, el método que Cartagena empleaba, por lo que el subarquetipo del que descienden ambos códices bien podría ser una copia próxima a la minuta o borrador (Morrás 2002a, pp.224226), redactada por el traductor como primera versión con alternativas, y que luego habría de ser sometida a correcciones.

Sea como fuere, $M$ y $S$, en los que todas las Declamaçiones menos una aparecen ya seguidas, representarían un estado de reordenación, que probablemente hay que atribuir al propio Cartagena, del conjunto de las obras (Morrás 2002, p.110). Aunque no sería la versión definitiva del conjunto de los Libros de Séneca, sí que sería ya el estado 'final' de las Declamaçiones, reunidas en una sola serie y sacadas las tres 'sueltas' de la Copilaçión. Por ello damos precedencia en nuestra edición a estos testimonios y asumimos el stemma (c) que propone Round, aunque en él habría que considerar m no como un arquetipo con un texto fijo sino más bien como un original sometido a modificaciones a medida que Cartagena lo retoca y del que, en estadios distintos, van surgiendo descendientes con diversa fisonomía (proceso habitual de transmisión en las traducciones medievales, como explica Morrás 2002a, p.227).

A falta de un examen completo de los manuscritos que atienda a su contenido íntegro, la tercera propuesta de Round nos parece satisfactoria. La colación de nuestros testimonios, sin embargo, sí nos da pie para confirmar relaciones entre manuscritos con apoyo textual y no basadas únicamente en la citada collatio externa. Así, en nuestro aparato crítico hemos consignado un total de 517 pasajes en los que hay lecturas 
discrepantes entre los testimonios elegidos para la edición y que van más allá de las variantes meramente gráficas que señalamos más abajo y no tenemos en cuenta. Ello permite establecer afinidades entre los distintos testimonios, a partir del número de variantes conjuntivas. Las cifras más relevantes en lo que se refiere a las lecturas que comparten nuestros manuscritos son las siguientes:

$\begin{array}{lr}\text { lecturas comunes exclusivas de } M \text { y } S & 31 \\ \text { lecturas comunes entre } M, S \text { y al menos otro } & 74 \\ \text { lecturas comunes exclusivas de } P \text { y } e & 31 \\ \text { lecturas comunes entre } P, e \text { y al menos otro } & 67 \\ \text { lecturas comunes exclusivas de } N \text { y } E & 12 \\ \text { lecturas comunes entre } N, E \text { y al menos otro } & 106 \\ \text { lecturas comunes exclusivas de } E \text { y } O & 2 \\ \text { lecturas comunes entre } E, O \text { y al menos otro } & 64 \\ \text { lecturas comunes exclusivas de } M, S \text { y } N & 3 \\ \text { lecturas comunes entre } M, S \text { y } N \text { y al menos otro } & 49\end{array}$

Las afinidades más claras que muestran estas cifras (sin entrar a discriminar si en su base se hallan auténticos errores, lecturas correctas o coincidencias sin origen genético) son las que hay entre $M$ y $S$, por un lado, y $P$ y $e$, por otro. $M$ y $S$ comparten en exclusiva 31 lecturas (algunas de ellas reproducidas más arriba) y presentan en común entre los dos, pero también con otros testimonios, 74 más. En cifras muy similares se mueven $P$ y $e$, que coinciden también en 31 lecturas exclusivas de ambos, a las que hay que añadir otras 67 compartidas con algún otro códice. Pueden citarse a título de ejemplo las siguientes:

I 5, 19 matarian $M S N O:$ mataran Pe

I 5, 29 dos iguales $M S N:$ dos cosas iguales $P e$

I 5, 30 recontar $M S N O$ : retornar $P e$

III 9, 27 a un siervo om. Pe

IV 4, 10 acusanle $M S N E O$ : recusanle $P e$

IV 4, 29 acaesçe $M S N E O$ : contesçe $P e$

$\mathrm{V} 1,29$ yo ove $M S N E O$ : ove yo $P$ e

V 7, 7 aquella $M S N E O:$ la $P e$

$\mathrm{V} 7,14$ de noche om. Pe

$\mathrm{V} 7,23$ tanto om. Pe

V 5, 19 desvergonçada $M S N E O:$ desvengada $P e$

VI 6,27 alegres fachas $M S N O$ : alegres fechas $E$ : alegrías hechas $P e$

VI 6, 29 o juezes $M S N E O:$ o juez $P e$

III 8, 34 partes $N E O$ : partese $P e$

Esta situación no hace sino confirmar, a nivel textual, los postulados 'externos' propuestos por Round y Morrás, que relacionaban $M$ y $S$ con el tipo $\alpha$ o la 'familia B' y situaban $P$ y $e$ dentro del tipo $\varepsilon$ o de la 'familia A'. Más complejas se presentan las relaciones entre los otros tres testimonios, $N, E$ y $O$. Para Round, la afinidad se da- 
ría principalmente entre $N$ y $E$, ya que ambos pertenecerían al tipo $\gamma$, mientras que $O$, del tipo $\delta$, no guardaría relación directa con los manuscritos que hemos seleccionado. Las 12 lecturas que comparten exclusivamente $N$ y $E$ y las 106 que tienen en común entre sí y con otros testimonios abonarían esta idea. Para Morrás, sin embargo, los lazos se darían más bien entre $E$ y $O$ (ambos de la 'familia C'), mientras que $N$, al situarse en la familia B, guardaría relación con $M$ y $S$. Las cifras de lecturas consignadas más arriba pueden apoyar también, como se ve, esta opción (más aún si tenemos en cuenta que a $E$ le faltan las tres primeras controversias, con lo que las cifras de coincidencias se refieren sólo a unas tres cuartas partes del texto total).

Acudiremos por ello a un último indicio numérico: las variantes que son únicas a cada uno de los siete testimonios, ya sea porque divergen (a) frente a una única lectura común de los otros seis (primera columna), o (b) frente a todas las lecturas de los demás testimonios, en las que éstos no coinciden unánimemente:

$\begin{array}{ccc}M & 5 & 25 \\ S & 39 & 80 \\ N & 6 & 20 \\ E & 11 & 17 \\ O & 50 & 120 \\ P & 56 & 123 \\ e & 53 & 109\end{array}$

Como puede verse, entre $N, E$ y $O$ es $O$ el que mayor 'independencia' muestra; es, además, el único de los testimonios que trae todas las declamaciones seguidas, incluyendo el fragmento de III 8, sin que falte ninguna. Nos inclinamos por ello más hacia la propuesta de Round, que sitúa a $O$ dentro de un tipo, $\delta$, del que es el único representante entre los manuscritos que hemos seleccionado.

Hay, además, otro hecho que apunta a la independencia de $O$ y que nos aporta un dato más acerca del progreso de Cartagena en la traducción de las Controuersiae. Como se ha visto, en $M$ y $S$ falta la última de ellas, III 8; en ambos, también, las $D e-$ clamaçiones son la última obra del manuscrito. ¿Las omitieron los copistas o Cartagena aún no la había traducido? Parece más bien lo último, porque en $O$ encontramos, entre VI 6 y III 8, esto es, entre lo que es el último texto de los incompletos $M$ y $S$ y la última controversia de la versión definitiva, un colofón 'residual'. En efecto, la suscriptio que antes reproducíamos puede leerse con ligeras variantes (Madrid, Biblioteca Nacional, ms. 8188 , fol. $206^{\text {r }}$ :

Aquí se acaba vna breue copilaçion de algunos dichos de Seneca sacados de vna grand copilaçión de sus dichos e doctrinas. Fue fecha e fueron torrnados de latyn en lenguaje castellano por mandado del muy alto personaje e muy poderoso rey don Iohan el segundo e non van situados por ordenança por quanto fueron trasladados acaso segund que cada vno en leyendo le bien paresçió e annadiéronse las glosas algunas adiçiones en los lugares donde el dicho sennor rey mandó.

Después, sin embargo, viene el texto de III 8 que no aparecía en $M$ y $S$, por lo que, deducimos, Cartagena tradujo primero las tres declamaciones que incluyó en la ver- 
sión original de la Copilaçión, luego otras seis y, por fin, III 8: la aparición de este texto en este lugar es testigo de este proceso, que la labor de un copista poco autónomo nos ha conservado en el lugar que le había correspondido y que confirma la independencia de $O$ con respecto a los otros manuscritos con los que hemos constituido nuestro texto castellano. Con todo, y a la vista de las lecciones singulares que presenta este manuscrito (estamos, sobre todo, ante errores), el valor textual de este testimonio es sensiblemente inferior al de otros.

En cuanto a la presentación del texto castellano, nos hemos basado fundamentalmente en las lecturas que proporcionan $M$ y $S$, por representar el estadio más antiguo de la versión que, según coinciden Round y Morrás, fue revisada por el propio Cartagena, corrigiéndolos cuando la ocasión así parecía aconsejarlo (por errores de copia, sobre todo). Hemos respetado, en general, las grafías que presenta $M$, aunque las hemos sometido a una regularización 'estándar' (puntuación, acentuación y uso de mayúsculas con criterios modernos; resolución de abreviaturas; regularización del uso de $u / v$ e $i / j$ con valor vocálico/consonántico; eliminación de geminadas sin valor fonético, etc.).

El aparato crítico, como puede verse, es positivo: se consignan en él todas las variantes que tienen relevancia para la constitución del texto o que suponen lectiones claramente discrepantes, sin prestar atención a vacilaciones o divergencias meramente gráficas o de usos lingüísticos (leísmos y loísmos, imperfectos de subjuntivo en - ra o -se, desinencia de segunda del plural en -des, etc.) que responden al 'diasistema' en el que habría que situar el conjunto de copias de muchas traducciones medievales (Morrás 2002a, pp.219-220). Con respecto a otras convenciones adoptadas en la presentación del texto y del aparato han de hacerse las siguientes aclaraciones:

- hemos siglado con $\Omega$ los casos en los que todos los testimonios utilizados coinciden frente a la lectura de uno solo de los códices;

- hemos numerado las líneas de manera continua en cada controversia, para facilitar la localización y la referencia en otras partes de este trabajo;

- hemos mantenido la referencia de número y controversia del original de Séneca el Viejo, por no añadir una numeración a la ya existente y porque la propia traducción los transmite con fidelidad;

- la indicación 'deest' o 'desunt' que se atribuye a algunos testimonios en la línea 1 del aparato de varias controversias se refiere a la controversia entera en cuestión.

\section{EL TEXTO LATINO}

Es casi un lugar común entre los estudiosos de la recepción de los autores clásicos en la Edad Media y el Renacimiento subrayar la 'inutilidad' de las ediciones críticas modernas si lo que se busca es una aproximación al texto antiguo que tal o cual lector tuvo a su disposición en los siglos XV o XVI. Es bien sabido que alrededor de un par de siglos de filología 'moderna' han conseguido proporcionarnos textos que se acercan lo más posible a un remoto e inalcanzable original, pero el resultado de ello es que las 
divergencias textuales entre nuestros Virgilios y Cicerones y los que manejaban los humanistas son más que palpables y, en muchas ocasiones, muy considerables.

Nuestro propósito es, lógicamente, proporcionar un texto latino sincrónico, esto es, que no intente remediar las deformaciones acarreadas por la transmisión, sino que se acerque al modelo subyacente que, según podemos deducir, tuvo ante sí Alonso de Cartagena. Para ello acudiremos a dos ediciones críticas 'modernas' y a varios testimonios manuscritos examinados directamente, sin perder de vista, como señala Morrás (2002a, p.222) que la mayoría de las veces no es que el manuscrito original al que haya acudido el traductor sea inencontrable, sino que el 'texto' latino que está en la base de la versión vernácula no se halla, como tal, en ningún códice concreto, sino que es resultado de un complejo proceso en el que intervienen diversos factores que se superponen a la mera lectura directa el texto antiguo.

Los excerpta de las Controuersiae no han sido muy bien tratados por la filología de las dos últimas centurias: al ser una versión truncada del original de Séneca, sometida a las alteraciones que ya hemos visto, en algunos casos ni siquiera se edita el texto completo (es el caso de la colección Loeb, por ejemplo). El editor más reciente de las Controuersiae, Lennart Håkanson, sí que se ocupó en su volumen de la Bibliotheca Teubneriana (Leipzig, 1989) de incluir la versión excerptoria de aquellos libros de los que también disponemos en versión completa. Sin embargo, como explica muy brevemente en su Praefatio (Håkanson 1989, pp.XIV-XV), acude principalmente al que la crítica reconoce como manuscrito más antiguo, el Montepessulanus H $123(M)$, en el que hay numerosas correcciones de al menos dos manos que Håkanson consigna debidamente; sólo de vez en cuando alega lecturas de códices más recientes, que o bien atribuye a un genérico recc. o, excepcionalmente, a ejemplares concretos que en esos casos identifica. Por ello, la mayor parte de su aparato crítico, en esta parte del texto, acaba ocupada por las lecturas de $M$ que no puede asumir y que se ve obligado a modificar a favor de conjeturas modernas o del texto de los recentiores.

La edición que más información crítica recoge es la de H. J. Müller (Viena, etc., 1887), que acude a un número mucho mayor de testimonios. En el aparato crítico del texto latino que ofrecemos hemos seleccionado las lecturas que consideramos más significativas (no es cuestión, lógicamente, de reproducir los aparatos de estos editores, mucha de cuya información resulta superflua a nuestro propósito), y hemos respetado las siglas utilizadas por Müller para los recentiores y por Håkanson y Müller para los manuscritos más antiguos y de mayor relevancia textual. Algunas de ellas $(M, P$, $S$ ) coinciden con las siglas que hemos atribuido a los testimonios del texto castellano, pero hemos preferido conservar la notación tradicional con la única adición de una 'c' (de 'Controuersiae') suscrita, con el fin principal de que no aparezcan en los aparatos críticos siglas que, siendo las mismas, designen testimonios distintos. Para mayor claridad, cuando nuestro texto diverge del que Håkanson y/o Müller proporcionan en sus ediciones, consignamos también las lecturas de estos editores con las siglas Håk y Müll; a ello hay que añadir las conjeturas de diversos estudiosos que transmite principalmente Müller y que hemos recogido en el aparato, cuya correspondencia es la siguiente: 


$\begin{array}{ll}M_{c} & \text { Montpellier, Montepessulanus H 123 } \\ P_{c} & \text { Paris, Bibliothèque nationale, Parisinus latinus } 7836 \\ S_{c} & \text { Paris, Bibliothèque nationale, Parisinus latinus } 16592 \\ a & \text { Sankt Gallen, Biblioteca del Monasterio, 221 } \\ b & \text { Berlin, Staatsbibliothek, Diez. C fol. 4 } \\ g & \text { Paris, Bibliothèque nationale, Parisinus latinus } 8542 \\ m & \text { Paris, Bibliothèque nationale, Parisinus Mazarinaeus } 1261 \\ l & \text { Città del Vaticano, Vaticanus latinus 1773 } \\ n & \text { editio princeps (Neapolis 1475) } \\ p & \text { Paris, Bibliothèque nationale, Parisinus latinus } 8717 \\ r & \text { Città del Vaticano, Vaticanus Reginensis 1637 } \\ \text { Müll } & \text { H.J. Müller (Viena, etc., 1887) } \\ \text { Håk } & \text { L. Håkanson (Leipzig, 1989) } \\ B s & \text { Conradus Bursian } \\ F b & \text { Nicolaus Faber } \\ F r o b & \text { editio Frobeniana (Basilea, 1515) } \\ G r & \text { Johannes Fredericus Gronov } \\ \text { Herv } & \text { editio Hervageniana (Basilea, 1557) }\end{array}$

A las variantes aportadas por la edición crítica de Müller y, en menor medida, de Håkanson, hemos añadido las procedentes del examen directo de dos códices depositados en bibliotecas españolas y no considerados por estos editores, que, como ya hemos indicado, tienen poco interés por transmitir únicamente la rama excerptoria de la tradición. El primero de ellos, Biblioteca Nacional de Madrid 10238, es un códice con varias obras de Séneca que circuló por la Castilla de Juan II (Olivetto 2011, pp.43-44). Schiff (1905, pp.102-103) lo incluye entre los libros del marqués de Santillana, aunque Round (1991, p.68), sin cuestionar el carácter cortesano de este códice, pone en duda que su propietario fuera precisamente el marqués. Este manuscrito incluye una versión, hoy mutilada, de los excerpta de las Controuersiae (fols. 109 ${ }^{\mathrm{v}}$ $128^{\mathrm{v}}$ ): de la mitad de IV 4 en fol. $118^{\mathrm{v}}$ se pasa a V 5 en fol. $119^{\mathrm{r}}$, por haberse arrancado en algún momento un folio que ni siquiera se había numerado. Estas dos controversias están, así, incompletas y, lógicamente, falta V 1, que estaba entre ambas. Además, de V 6 se pasa a V 8, saltándose, ya sin motivos materiales, V 7; por último, de los diez libros de la obra original este códice transmite sólo nueve: el numerado como VIII es en realidad el IX y el numerado como IX es el X, por lo que el que falta es el VIII (cuya segunda controversia es una de las traducidas por Cartagena). Esta serie de carencias textuales deja claro que no pudo ser el texto que Cartagena tuvo delante, pero el hecho de que nos conste su presencia en la corte del rey Juan nos lleva a tenerlo en cuenta como testimonio, que hemos siglado $A$, para la reconstrucción de un texto latino que es probable que guardara alguna relación con el transmitido por este manuscrito.

El otro códice al que hemos acudido es el Escorial S.II.3, que también contiene varias obras de Séneca o a él atribuidas y en el que los excerpta de las Controversiae abarcan los fols. $127^{\mathrm{r}}-155^{\mathrm{r}}$. En este ejemplar aparece la misma omisión de V 7 (en fol. 
$142^{r}$ ) y la misma confusión y supresión del libro VIII completo que acabamos de describir, por lo que es evidente que entre los dos códices existe algún parentesco sobre el que poco podemos decir más allá de constatarlo. Con el recurso a este manuscrito, que siglamos como $T$, al anterior y a las ediciones críticas citadas, proporcionamos un texto latino que intenta aproximarse al modelo subyacente que Cartagena hubo de tener a su disposición.

Como es lógico, el texto castellano que da Cartagena nos ha guiado más de una vez a la hora de elegir las variantes que hemos incluido en nuestro texto latino sincrónico 'reconstruido'. Los pasajes en los que las divergencias con las ediciones críticas modernas son más evidentes son los siguientes:

\section{Cartagena}

VIII 2, 33 los dioses quisieron

III 9,14

el heredero (del señor deste siervo)

III 9, 20 mas quiso (este siervo)

III 9, 24 este siervo

III 9, 25 a su señor que estava loco

III 9, 27 a un siervo

III 9, 28 Tarquino

III 9, 45 los tribunos bivos

III 9, 46 Non deve ser el ladron mas penado

V I, 37 quitara

$\mathrm{V} 7,31$ destos tresçientos ombres

V 7,32 se pudiesen quexar

$\mathrm{V} 7,36$ esto por çierto

V 5, 20 devía vençer

$\mathrm{V} 5,21$ entre el rico e el pobre

V 5, 26 non ... cosa mas plazentera

$\mathrm{V} 5,44$ ponedes ... en lo alto

V 5, 48 agora vuestros quinteros

VI 6, 7 [sin traducir]

VI 6, 21 el adulterio se allega por señal de otro malefiçio

VI 6, 31 los fados
Texto latino

dii ... uellent

heres

maluit

seruus

furiosum

seruum

Tarquino

uiui ... tribuni

Ita ne fur ei praeferatur

tollat

illis trecentis

agi possent

certe hoc

expugnetur

inter me et pauperem

nihil laetius

agunt in summis

nunc uillici

crudelitatis

adulterium

argumentum est
Håkanson y/o Müller

Elii uellent

erus

malui

seruum

furiosus

serua natum

Tarquiniis

serui uiuorum ... tribuni

Itane, furcifer, tu

tot ille

trecentis

argui posset

certe

expellatur

inter te et pauperem

nihil lautius

in summis / ut sint in summis

uillici

cruditatis

adulterium argumentum

ueneficii est /

ueneficium adulterii

argumentum est

facta 
Estas discrepancias, como era de esperar, confirman que el texto que manejó Cartagena era el de la uulgata de esta obra; por ello, aun en las ocasiones en las que la traducción romance no sirve de ayuda para decidirse por lecturas alternativas, nos hemos inclinado, cuando lo hay, por el acuerdo de varios recentiores frente al texto de las ediciones críticas, por considerarla la solución más probable (como puede verse en nuestro aparato crítico).

\section{LA TRADUCCIÓN}

El interés de Alonso de Cartagena por la traducción, desde el punto de vista tanto teórico como práctico, es uno de los rasgos más acusados de su personalidad como intelectual: sin ir más lejos, la polémica en la que se enzarzó, a cuenta de la versión latina de la Ética de Aristóteles redactada por Leonardo Bruni, es uno de los debates más interesantes del humanismo del siglo XV (González Rolán et al. 2000, Morrás 2001). Por otro lado, su faceta de traductor incansable nos ha dejado las versiones de Cicerón y de Séneca de las que ya hemos hablado, sobre las que han fijado su atención varios estudios de los últimos años. Así, no solo la aproximación general de Cartagena a esta labor fue presentada con considerable extensión ya por Round en 1993 (pp.108-109, 116-118, 132-134 y 138-147), sino que su trabajo concreto en varias de sus versiones ha sido detalladamente descrito en los casos de Cicerón (Morrás 1996, Round 1998, Baldissera 2002), o del De uita beata y el De clementia de Séneca (Round 1998). Precisamente en su breve pero enjundioso estudio sobre estas últimas obras subraya Round lo que a primera vista más llama la atención al comparar las versiones de Cartagena con los originales latinos: la mucha mayor extensión de aquéllas, que no quedaría suficientemente explicada por el carácter más analítico del romance frente al latín. En efecto, según señala este autor (Round 1998, pp.2021), la traducción del De uita beata elaborada por Cartagena contiene un $70 \%$ más de palabras que el texto latino, mientras que para el caso del De clementia el cómputo llega a doblarse. Pues bien, el caso que nos ocupa es aún más extremo: el texto latino contiene un total de 2.417 palabras, y Cartagena utiliza 6.297 en su versión castellana, lo que da una proporción de 2,6, esto es, un incremento del $160 \%$ frente al $70 \%$ o el $100 \%$ que Round detecta para las citadas obras filosóficas de Séneca; la simple comparación visual de las páginas de texto castellano con las de texto latino en la edición que ofrecemos ilustran este asunto.

Ello es debido, en parte, al carácter peculiar de este texto frente a las obras filosóficas de Séneca. En efecto, la versión de Cartagena incluye en todos los casos textos que no se corresponden con el original, pero que son necesarios para la comprensión por parte del lector. Así, las leyes que en las Controuersiae de Séneca aparecen formuladas sin más, son siempre introducidas en la versión castellana con frases del tipo «En una çibdad avía una ley que dezía así» (I 5), «Los elios tenían una ley que dezía así» (VIII 2), «En Atenas avía una ley que dezía así» (III 8), etc. Lo mismo ocurre con la presentación del caso supuestamente acaecido sobre el que se redactan las declamationes en cuestión: en la obra latina aparece de manera sucinta y sin in- 
troducción alguna; el traductor prefiere, sin embargo, añadir sistemáticamente un «el caso es este» que aclara al lector ante qué está.

De manera parecida actúa con la presentación de los dos 'discursos' (aunque, como ya hemos señalado, no se trata de auténticas orationes sino de sententiae acumuladas $\mathrm{y}$, en principio, inconexas): Cartagena se toma la molestia de aclarar quién habla y en defensa de qué postura, cuando en el original latino la exposición del caso ya deja claro quién interviene en primer lugar y a las palabras de la parte contraria les precede un simple 'pars altera', y no siempre (así, por ejemplo: «Fabla este abogado contra la otra forçada que pide al forçador por marido» en I 5, «Dize el acusador contra este cavallero» en IV 4, «Dize la parte del pobre contra el rico» en V 1, etc.). Cartagena se decide así a ejercer su autoridad mediante la intervención directa en la ordinatio del texto, actitud que, como ha señalado Conde (2012, pp.159-160), es una de las escasas instancias en las que la figura del traductor se hace deliberadamente visible. De este modo, aplica un criterio de disposición textual que ya había defendido en otros lugares: en una de sus epístolas dirigidas a Pier Candido Decembrio en 1438, a cuenta de la traducción al latín de la República de Platón que este humanista italiano iba redactando por entonces, Cartagena hace referencia explícita a la necesidad de distinguir gráficamente a los interlocutores de un diálogo (texto en González Rolán et al. 2000, p.386), práctica que él mismo adopta en su traducción del De senectute ciceroniano (Morrás 1996, p.129-130).

La exposición del caso suele ser extremamente concisa en la versión latina; la traducción, por el contrario, se ayuda constantemente de paráfrasis y de adiciones aclaratorias. La primera de las versiones (I 5) es una muestra palmaria: frente a las diez palabras del original («Vna nocte quidam duas rapuit. Altera mortem optat, altera nuptias»), Cartagena aclara que las «duas» son «dos mugeres», mientras que los dos objetos directos que en el original son sencillos sustantivos (mortem y nuptias) se transforman en sendas subordinadas, la segunda de las cuales resulta muy ampliada («que gelo den por marido sin que ella le dé dote alguno»). Si suprimimos del cómputo realizado antes las partes del original y de la traducción que corresponden a estos pasajes 'circunstanciales', y también los títulos de cada controversia (que en la versión de Cartagena son más profusos en información localizadora), la proporción varía ligeramente: el latín de Séneca se queda justo en 2.000 palabras, mientras que el castellano de Cartagena se eleva a 4.856; esto es, la ratio baja de 2,6 a 2,43, lo que sigue estando lejos del mero 2,0 que calculaba Round como máximo para el De clementia. La razón principal para ello, creemos, es clara: Cartagena recurre a los procedimientos textuales que le son característicos (Morrás 1996, Round 1998), pero se ve en la necesidad de realizar un esfuerzo mayor que lo habitual si lo que quiere es presentar como un discurso inteligible y cohesionado lo que en el original son sententiae 'aisladas' que Séneca ha agrupado.

Es cierto que Cartagena se afana en ser un traductor 'literal' dentro de lo posible, y hay ejemplos de traducción muy pegada al texto; así el siguiente texto (I 5, 31):

Contumeliosum mihi erit te dignam uideri, in cuius honorem homo occidatur, me dignam non uideri, in cuius honorem homo seruetur.

se traduce por: 
Muy ofensoso sería a mí que tú seas avida por tan digna que maten al ombre por tu honra e que non sea yo avida por digna para que por mi honra escape.

Sin embargo, cuando el estilo epigramático propio de las sententiae del original produce fórmulas concisas como el siguiente paralelismo (IV 4, 18):

... ille uiro arma, ego armis uirum

Cartagena lo convierte en

... yo non tenía armas e prestómelas el cavallero finado, e él non tenía cuerpo para pelear e yo presté a sus armas varón bivo que pelease con ellas

con lo que ha utilizado 28 palabras para traducir seis (acaso Cartagena, consciente del exceso, suprimió el 'para pelear' en la versión que traen $M$ y $S$ ). $\mathrm{O}$, de manera más extrema, y por citar tan sólo otro ejemplo de los muchos que podrían aducirse, otra estructura similar de paralelismo (IV 4, 45) como

unum uirum fortem honorauimus, alterum uindicemus.

se ve ampliada hasta multiplicar por seis el número de palabras en

e pues onramos a este cavallero bivo como a varón fuerte porque se ovo bien en la batalla, así devemos vengar al cavallero finado la injuria que resçibió en ser tomadas las armas de su sepultura.

A pesar de que hay glosas marginales, las necesarias de realia se introducen a veces en el propio texto (así «Fidias, que era un ofiçial muy sotil de fazer imágines», VIII 2, 10; o «Júpiter olimpio que ellos tenía por su dios», VIII 2, 12). Cartagena también se decide de vez en cuando por equivalentes culturales (talentum='marco de oro' en VIII 2, 13 y 15), aunque se anima a conservar un hercule traduciéndolo por «yo te juro por Hércules» (IV 4, 41). La cuestión de cierta disonancia cultural e ideológica entre el mundo antiguo y el mundo moral del siglo XV, que se deja traslucir en la traducción y que ya señaló Round (1998, p.22), parece aflorar también aquí en varias ocasiones. Así, cuando Cartagena traduce «más seguramente pelear con ella [la Fortuna]» $(\mathrm{V} 1,17)$ el simple «tutius ... illam experiri», añade un matiz de combate posible contra la Fortuna que le resta fatalidad a esa fuerza incontrolable: no es difícil relacionar esta versión con el sempiterno debate cristiano sobre el libre albedrío y el problema de la predestinación. De manera análoga procede, pero esta vez advirtiendo a un suicida con palabras que no están en el original, cuando propone (V 1 18):

E si tú piensas que la muerte de tus fijos e de tu muger es tu destruimiento e te quieres matar por eso, yerras, ca aún puedes bevir.

como versión romance del simple y directo

maius tu tuum putas esse naufragium? 
Buena parte de los añadidos, sin embargo, corresponden, como decíamos, al esfuerzo por conectar frases inconexas. Un caso claro lo tenemos al final de VIII 2: en ese pasaje, las dos últimas frases no tienen relación entre sí (la invocación a los dioses y la admisión condicionada de Fidias); de hecho, el verbo en indicativo (recepimus) de la segunda deja claro que no hay relación sintáctica entre ambas; sin embargo el traductor las ha conectado. Así, en lugar de un 'Invoco a los dioses (...). Nos han devuelto a Fidias: (...)' (en la traducción de Adiego Lajara et al., 2005, p.121), Cartagena propone un «Yo juro por los dioses ... que resçibiéramos a Fidias ... » (VIII 2, 36).

Otras 'ampliaciones' obedecen también a este empeño por transformar en discursos coherentes y 'retóricos' la estructura 'suelta' del original (no olvidemos que Cartagena tradujo el Pro Marcello de Cicerón, por lo que además de su propio sentido de lo que es una oratio cabal, había tenido contacto intenso con los modelos antiguos). Así, cierto énfasis argumentativo al discurso en defensa del capitán de V 7 lo añade Cartagena en la última frase, que aunque traduce más o menos literalmente, culmina con un «si yo abriera las puertas» $(\mathrm{V} 7,29)$, que más que aclaración necesaria es reiteración argumentativa y vía para, una vez más, añadir coherencia al texto resultante:

Credo in insidiis hostes fuisse, ut exclusos occiderent, sequerentur admissos.

frente a

E yo creo bien que los enemigos estarían en alguna çelada para matar a estos que fuían e se entrar en la çibdad a vueltas con ellos si yo abriera las puertas.

En la misma línea de enriquecer el aspecto ‘dramático' de su versión están los casos en los que las terceras personas verbales del original se transforman en segundas, con lo que se pone ante el lector directamente un diálogo que en el original aparece referido al pasado, no actualizado y reproducido. Un caso claro de ello lo proporcionan varios pasajes de II 2. En la traducción de esa controversia, lo que en el original está en tercera persona, porque son palabras de la defendida que supuestamente refiere su abogado, aquí pasan a primera, al ponerse en boca de la mujer, por más que el parlamento se introduzca con la expresión «Dize la parte de la muger». Así, el «'Moriar', inquit, ...'» pasa a ser «Reprehéndeme mi padre porque dixe que quería morir por mi marido» (II 2, 14). Algo más adelante, cuando en el latín original se asegura, en tercera persona, renombre a esta mujer que así se ha entregado a su marido, en la traducción se prefiere la primera persona: «inter has puella uiua numeratur» pasa a ser «así moça como só e biva seré nombrada entre aquellas». Consecuencia de lo anterior, en esta línea de 'dramatización' del texto, es que las palabras que se atribuyen a la mujer en tercera persona por la parte contraria, se le dirijan, como en otros casos, directamente en segunda: “'Non possum', inquit, '...'» se vierte en «'Dizes tú, o muger, que non puedes...'» (II 2, 27).

De manera análoga, Cartagena añade a menudo increpaciones, apóstrofes e interrogaciones retóricas que no están en el original, pero que elevan el grado de 'retorización' del texto Así, una frase como

\section{Quid? Inambulantibus nobis non obstant seruorum cateruae?}


está introducida en castellano con una increpación al rico al que va dirigida y cerrada con una adición 'patética', acaso seducido Cartagena por cargar ligeramente las tintas de la elocuencia en la defensa de un pobre

e díme, ¿qué maravilla hay en esto?: ca veemos que quando andamos por la calle algund embargo nos fazen los siervos que andan de una parte a otra, mas non los matamos por eso.' (V 5, 30)

En fin, otro ejemplo de unas líneas más abajo sería el de «Liceat et pauperem gaudere prospectu», que se introduce también con increpación explícita, a los ricos en general, por lo que la afirmación se transforma en pregunta retórica (V 5, 22):

E dezidme, o ricos, ¿non vos paresçe que es razón que el pobre aya algund plazer en mirar sus árboles?

La traducción de Cartagena, en suma, presenta las características y procedimientos ya estudiados en otras de sus versiones; ésta se diferencia de las demás, sin embargo, por acudir en medida mucho mayor a los habituales recursos explicativos, por un lado, y por la vertiente 'dramatizadora' o 'retórica' que quiere conferir a un texto que se apartaba considerablemente de la línea moralizadora presente en el resto de 'Séneca'.

\section{REFERENCIAS BIBLIOGRÁFICAS}

Adiego Lajara, I.J., Artigas Álvarez, E., Riquer Permanyer, A. De (2005), «Introducción», en SÉneCa el Viejo, Controversias. Suasorias, I, Madrid, Gredos, pp.7-79.

Baldissera, A. (ed.) (2003), A. de Cartagena, Por Marcelo, Viareggio, Mauro Baroni.

BLÜHER, K.A. (1983), Séneca en España. Investigaciones sobre la recepción de Séneca en España desde el siglo XIII hasta el siglo XVII, Madrid, Gredos.

Cartagena, A. de (1491), Cinco libros de Séneca, Sevilla, E. Polono y C. Ungut (ejemplar de Biblioteca Nacional de Madrid, INC/661).

Conde, J.C. (2012), «Prácticas paratextuales y conferencia de capital simbólico: los prólogos a las traducciones del siglo XV en la Península Ibérica», Cahiers d'études hispaniques medievales 35, 141-163.

Fernández Gallardo, L. (2008), «Alonso de Cartagena y el humanismo», La Corónica 37, $175-216$.

Fernández López, J. - Río SAnz, E. Del (e. p.), «Las ‘Tragedias' de Séneca en la ‘Copilaçión’ de Alonso de Cartagena», en Manipulus studiorum. Homenaje a A. M. Aldama, Madrid, Universidad Complutense.

FernÁNDEZ LóPeZ, J. (e. p.), «Retórica y derecho: Séneca el Viejo y 'fazañas' en la 'Copilaçión’ de Alonso de Cartagena», Actas del VII Congreso de la Sociedad de Estudios Latinos (Toledo, junio 2012), Madrid.

Gómez Redondo, F. (1998), Historia de la prosa medieval castellana. Tomo I, Madrid, Cátedra. GonzÁlez Rolán, T. (1996), «Los comienzos del Renacimiento en España: Alfonso de Cartagena», en Scripta Philologica in memoriam Manuel Taboada Cid, I, A Coruña, Universidade da Coruña, pp.417-432. 
González Rolán, T., Moreno Hernández, A., Saquero SuÁrez-Somonte, P. (2000), Humanismo y teoría de la traducción en España e Italia en la primera mitad del siglo XV. Edición y estudio de la "Controversia Alphonsiana» (Alfonso de Cartagena vs. Leonardo Bruni y Pier Cándido Decembrio), Madrid, Ediciones Clásicas.

GonzÁlez Rolán, T., SAquero SuÁReZ-Somonte, P. (1987-88), «El Epitoma rei militaris de Flavio Vegecio traducido al castellano en el siglo XV. Edición de los Dichos de Séneca en el acto de la caballería de Alfonso de Cartagena», Miscelánea Medieval Murciana 14, 101-150.

HÅKANSON, L. (ed.) (1989), L. Annaei Senecae Oratorum et rhetorum sententiae divisiones colores, Leipzig, Teubner.

IMPEY, O.T. (1972), «Alfonso de Cartagena, traductor de Séneca y precursor del humanismo español», Prohemio 3, 473-494.

Kaepelli, T. (1948), «Lucca Mannelli e la sua Tabulatio et expositio Senecae», Archivum Fratrum Praedicatorum 18, 237-264.

Lilao Franca, O. - Castrillo González, C. (2002), Catálogo de manuscritos de la Biblioteca Universitaria de Salamanca. II. Manuscritos 1680-2777, Salamanca, Universidad de Salamanca.

Mascagna, R. (ed.) (1969), A. de Cartagena, La Rethórica de M. Tullio Cicerón, Nápoles, Liguori.

MorrÁs, M. (1995), «Latinismos y literalidad en el origen del clasicismo vernáculo: las ideas de Alfonso de Cartagena (ca. 1384-1456)», en REciO, R. (ed.), La traducción en España, ss. XIV-XVI, León, Universidad de León, pp.35-58.

Morrás, M. (ed.) (1996), A. de Cartagena, Libros de Tulio: De Senetute, De los Ofiçios, Alcalá de Henares, Universidad de Alcalá de Henares.

Morrás, M. (2002), «Alonso de Cartagena», en Alvar, C. - Lucía Megías, J.M. (eds.), Diccionario filológico de literatura medieval española. Textos y transmisión, Madrid, Castalia, pp.93-127.

Morrás, M. (2002a), «El texto en su laberinto: para la edición crítica de las traducciones medievales», La Corónica 30, 203-247.

Morrás, M. (2002b), «El debate entre Leonardo Bruni y Alonso de Cartagena: las razones de una polémica», Quaderns. Revista de traducció 7, 33-57.

Morrás, M. - López CASAs, M.M. (2001), «Lectura y difusión de los Libros de Séneca (a propósito de un testimonio desconocido)», RFE 81, 137-167.

Müller, H.J. (ed.) (1887), L. Annaei Senecae Oratorum et rhetorum sententiae, divisiones, colores, Viena, F. Tempsky.

MuÑoz JimÉNEZ, M.J. (2004), «Seneca in declamationibus: las Controversiae de Séneca el Viejo en extractos», Revista de Estudios Latinos 4, 163-176.

Olivetto, G. (2011), Título de la Amistança. Traducción de Alonso de Cartagena sobre la 'Tabulatio et Expostio Senecae’de Luca Mannelli, San Millán de la Cogolla, Cilengua.

Olivetto, G. (2011a), «La collatio externa: en el principio era el códice», Incipit 31, 13-33.

ORdunA, G. (1983), «La collatio externa de los códices como procedimiento auxiliar para fijar el stemma codicum. Crónicas del Canciller Ayala», Incipit 3, 3-53.

OrdunA, G. (1991), «Ecdótica hispánica y el valor estemático de la historia del texto», Romance Philology 45, 89-101.

Round, N.G. (1991), «Alonso de Cartagena and John Calvin as interpreters of Seneca's De clementia», en Osler, M.J. (ed.), Atoms, pneuma, and tranquillity: Epicurean and Stoic themes in European thought, Cambridge, Cambridge University Press, pp.67-88. 
Round, N.G. (1993), Libro llamado Fedrón. Plato’s Phaedo translated by Pero Díaz de Toledo, Londres, Tamesis.

Round, N.G. (1998), «Perdóneme Séneca: The translational practices of Alonso de Cartagena», Bulletin of Hispanic Studies (Glasgow) 75, 17-29.

Round, N.G. (2002), «Alonso de Cartagena's 'Libros de Séneca': Disentangling the manuscript tradition», en Collins, R., Goodman, A. (ed.), Medieval Spain. Culture, conflict and coexistence. Studies in honour of Angus MacKay, Houndmills (NY), Palgrave \& MacMillan, pp.123-147.

Ruiz García, E. (2004), «En torno a los romanceamientos de Séneca en el Cuatrocientos», en Robertis, T. DE, Resta, G. (eds.), Seneca: una vicenda testuale (Mostra di manoscritti ed edizioni. Firenze, Biblioteca Medicea Laurenziana, 2 aprile - 2 luglio 2004), Florencia, Mandragora, pp.65-82.

Saquero SuÁrez-Somonte, P., GonzÁlez Rolán, T. (1991), «Actitudes renacentistas en Castilla durante el siglo XV: la correspondencia entre Alfonso de Cartagena y Pier Cándido Decembrio», $C F C(L)$ 1, 195-232.

Schif, M. (1905), La bibliothèque du Marquis de Santillane, París, Émile Bouillon.

Toselli, L. (2007), La 'Tabulatio et Expositio Senece' di Luca Mannelli. Saggio di Edizione, Milán, Università Cattolica del Sacro Cuore (tesis doctoral inédita).

Winterbottom, M. (ed.) (1974), The Elder Seneca. Controversiae I-VI, Cambridge (Mass.) Londres, Harvard University Press \& W. Heinemann. 


\section{En el tratado del forçador e del robo [I 5]}

Que un ombre forçó dos mugeres, e la una pide que lo maten e la otra pide que gelo den por marido sin que ella le dé dote alguno.

5 En una çibdad avía una ley que dezía así: 'La muger forçada puede escoger una de dos cosas, o que maten al forçador o que gelo den por marido sin que ella le dé dote alguno'. El caso acaesçió desta manera: uno forçó en una noche dos mugeres; la una pide que le maten, la otra demanda que gelo den por marido.

10 Dize el abogado de la que pide que le maten: «A este ombre acusan de fornicaçión fecha por fuerça, e él defiéndese con otra forçosa fornicaçión; e la una muger forçada acusándole pleytea con él, e la otra quiérele defender del pleyto. ¡Vengad, o padres, tal malefiçio! Levántese fuertemente el crúo rigor de la pública justiçia a castigar tal malefiçio: ¡ya se fuerçan las mugeres a pares! Ajuntado anda el pueblo e espantado

15 desto como de un público e general miedo, e duro han de creer que uno cometiese maldad de dos forçadores. A la una forçó por cumplir su mala voluntad, e a la otra forçó para que le defendiese de la fuerça primera. Ya te matarían, o forçador, si non porque meresçes dos vezes la muerte».

20 Fabla este abogado contra la otra forçada que pide al forçador por marido: «Si forçara a ti primero e tú le pidieras por marido, e después forçara a esta otra ante que tú casases, ¿dirías que non devía morir pidiendo la otra forçada que muriese? Por çierto tú non puedes otra cosa otorgar a tu forçador salvo que non muera por la fuerça que en ti fizo, mas non tienes derecho alguno sobre la fuerça que fizo a la otra, ca tú non puedes fazer

25 otra grazia a tu forçador salvo que non muera por ti, mas non le puedes librar que otro non le mate por otra causa diversa».

Dize la otra parte: «Quando son dos iguales sentençias contrarias, la más mansa deve vençer. Remembra a Virginia, puedes recontar a Lucreçia, pero muchas más fueron las

30 savinas. Muy ofensoso sería a mí que tú seas avida por tan digna que maten al ombre por tu honra e que non sea yo avida por digna para que por mi honra escape.»

\section{En el tratado del sacrilegio [VIII 2]}

Cómo los elios pidieron prestado a Fidias, que era muy sabio ofiçial, e después que ovo acabado la obra cortáronle las manos.

5 En la declamaçión déçima del libro sétimo. Llámase esta declamaçión la de Fidias el manco.

Los elios tenían una ley que dezía así: 'Corten las manos a quien cometiere sacrilegio'. El caso es este: los elios pidieron a los de Atenas que les prestasen a Fidias, que era un ofiçial muy sotil de fazer imágines, para que les fiziese en su templo una imagen de

10 Júpiter olimpio, que ellos tenían por su dios. E los de Atenas prestárongelo con tal condiçión, que fecha la obra lo tornasen o çient marcos de oro por él. Fidias fizo a Júpiter, e después que lo ovo fecho e acabado los elios dixeron que Fidias avía robado oro del templo e cortáronle las manos como a sacrílego. Piden los de Atenas los çient marcos de oro. Contradízenlo los elios. 
Dizen los de Atenas: «Nós de aquí adelante non podemos prestar a Fidias, ca este ofiçial estonçe podía fazer bien imágines de qualquier de los dioses quando en el coraçón lo pensava, e después por las manos lo obrava; ca la imagen de Júpiter primero la pensó en sí ante que para Júpiter la fiziese, e ya sin manos non lo podrá fazer. Vosotros sodes

20 sacrílegos, que cortastes las manos consagradas, e vuestro dios Júpiter la primera sangre que vio fue la sangre del ofiçial que lo fizo. Yo fago testigo a Júpiter, que es proprio dios de Fidias, que los ofiçios de manos mantienen a los ofiçiales que los saben e los sostienen en sus menesteres e trabajos, mas tu ofiçio, ¡o Fidias!, te fizo mesquino e cuitado. E nós por las manos de Fidias pusimos condiçión que nos le tornasen, ca non cuydedes que entendemos que nos tornades a Fidias, pues nos lo dades sin manos. Ca si non toviera manos non nos lo demandárades prestado. Prestámosvos ofiçial que podía fazer dioses e tornádesnos ombre que adorar non los puede. Non avedes vergüença, ca esto que dezides que fue sacrílego devedes a Júpiter, pues él vos lo fizo, e Fidias bive en quanto ombre, mas non en quanto ofiçial, pues manos non tiene. E vós non nos tornades

30 a Fidias, mas mostrádesnos la pena que a Fidias distes. Las manos que solían fazer dioses agora aun non pueden rogar a los ombres. Tan bien fizo a Júpiter que los dioses quisieron que esta fuese su postrimera obra. Las manos vos prestamos, las manos vos pedimos. En su acusaçión el testigo, e el acusador e el juez eran elios, e solamente el acusado era de Atenas. Yo juro por los dioses, así por aquellos que fizo Fidias como por

35 los que pudiera fazer, que confieso que resçibiéramos a Fidias si tal nos lo diéredes que lo podamos prestar».

Dize la otra parte: «Teníamos oro que fue otro tiempo de imágines sagradas, teníamos marfil: buscamos algún ofiçial que desta sagrada materia algo fiziese. Nuestro propósito 40 era que en otros templos Fidias fiziese imágines, mas non era tan nesçesario guarnesçer los dioses como es nesçesario vengarlos».

\section{En el tratado de la servidumbre del siervo [III 9]}

Que un ombre mandó que cruçificasen a un su siervo porque non le avía querido dar yervas.

5 En la declamaçión postrimera del libro terçero. Llámase esta declamaçión la de la cruz del siervo que non quiso dar yervas a su señor.

El caso es este: un señor estando doliente mandó a su siervo que le diese yervas a bever con que muriese e el siervo non lo quiso fazer. El señor mandó en su testamento a sus herederos que lo cruçificasen o fiziesen cruçificar. El siervo queréllase desto a los tribunos.

Dize el abogado del siervo: «O, ley cornelia, a ti llamo que me acorras, ca el heredero del señor deste siervo manda lo que tú viedas. E porque non piense alguno que este siervo fizo verdadero desplazer a su señor devedes saber que estonçes el señor lo mandó

15 cruçificar, quando pedía para sí mesmo yervas con que muriese. Confessamos los muchos errores que fizo este siervo: ¿e queredes saber quáles? Yo vos los diré: que non quiso dar malos bevedizos nin viandas dañosas a su señor. Mas dirá alguno: 'el señor lo quería, pues lo demandava'. Responderé yo: 'verdad es, pero más quiso este siervo padesçer muerte que meresçerla'. E ved agora en quánto peligro está puesto, ca si es vençido anlo de matar, e si non es vençido ha de servir a aquel que pide que lo 
cruçifiquen. De la una parte está la ley por él, de la otra es el testamento contra él, e de amas partes le está aparejado tormento. Este siervo non quiso matar sin causa a su señor que estava loco; ¿e queredes prueva de su locura? Non es menester otra salvo que quiso matar a sí mesmo. E dirá alguno: 'los tribunos non pueden acorrer al siervo nin le oír'; mas responderé yo: los romanos ya tovimos por rey a un siervo, e la traiçión que tenían tratada los fijos de Bruto con Tarquino, un siervo la descubrió. E si este siervo por esto que le acusan deve morir, síguese que non ay diferençia entre dar yervas a su señor non las querer dar, pues que por cada una destas cosas le matan. E por çierto aunque la muerte es algunas vezes remedio para algunas cosas e trabajos, pero siempre es maldad

30 el matar. E vosotros queredes que el siervo desesperase tan aína de la vida de su señor como desespera el heredero. E tú, o señor, si entendías que la muerte era tormento, ¿para qué pedías que te la diesen? Si entendías que era bien, ¿para qué amenazavas con ella a tu siervo? Nunca acusa alguno a otro de yervas si non quando las da. Dime tú, o acusador, ¿quieres limitar o acortar el poderío de los tribunos e non vees que el pueblo romano, por que siempre él mesmo pudiese más, quiso que los tribunos pudiesen más que él? Tener yervas es grand malefiçio: quánto más matar con ellas a su señor».

Dize la otra parte: «El señor quería morir e escogió a este siervo porque era malo e osado e rebelde que le diese la muerte, e non lo dexó este mal siervo de fazer porque quería la salud de su señor, mas porque le vio tener dolençia incurable e quiso que durase mucho su pena e afliçión. El siervo executor es de los mandamientos de su señor, non emendador, e seguir deve lo que le manda, non emendarlo. Veamos quánta fuerça tienen los testamentos e çiertamente todo el poderío dellos peresçería si los tribunos bivos non curasen de lo que mandan los testadores defuntos. Non deve ser el ladrón más penado que este siervo que fue tan rebelde, e más razón es que mueras tú, o siervo, segund la voluntad de tu señor, que morir nin bevir él a tu voluntad».

\section{En el libro quarto de las declamaçiones, la declamaçión quarta, que se llama la declamaçión de aquel que con las armas que tomó de la sepultura fue vençedor. Proponen contra él aquella acçión que llaman del sepulcro ofensado. [IV 4]}

El caso es este: una çibdad avía guerra con otra, e un cavallero de los buenos e denodados della peleando perdió sus armas en la batalla e tornó a la çibdad e fue a la sepultura de un buen cavallero que yazía enterrado e tomó las armas que çerca della estavan e fue a pelear con ellas e peleó fuertemente e vençió. E después de la pelea tornó las armas a la sepultura donde las avía tomado. E la çibdad dio a este cavallero su gualardón segund que suelen dar a los que bien pelean. Agora acúsanle que ofensó la sepultura en tomar las armas della.

15 Dize el cavallero acusado: «¡Mala vez llegué a estas armas e ellas se vinieron conmigo! E por çierto porque las yo tomé son ellas armas, ca si las dexara non fueran armas mas fueran despojo e robo de los enemigos. E aquello fuera verdaderamente quebrantamiento e ofensa de la sepultura si a ella llegaran los enemigos. Mas esto que yo fize non es quebrantamiento, ante fue manera de prestado, ca cada uno de nós prestó

20 al otro lo que le fallesçía: yo non tenía armas e prestómelas el cavallero finado, e él non tenía cuerpo para pelear e yo presté a sus armas varón bivo que pelease con ellas. E en esto la república ganó mucho, ca fue por ello defendida, e el cavallero finado non perdió 
en ello cosa alguna. E non nos devemos maravillar que por tamaña nesçesidad tomásemos las armas de la sepultura, ca vemos que quando ay tormenta en la mar, por escapar los ombres echan las mercadurías en el agua, e quando se ençiende fuego en la çibdad derriban casas por atajarlo, ca la nesçesidad es ley del tiempo e segund ella se deven guiar las leyes. E qualquier cosa por grave que sea se puede razonablemente fazer para defender la república e sus leyes. E más onra vino a esta sepultura por le tomar yo las armas que si non las tomara, ca tornégelas después de vençimiento. E más famosas e nombradas serán de aquí adelante, pues son vençedoras en defensión de la república. E muchas vezes acaesçe tomar las riquezas de los templos e las joyas de plata e fundirlas para dar sueldo a los cavalleros».

Dize el acusador contra este cavallero: «Acusamos aquí a un ombre que fue para poco en la batalla e fue osado después que fuyó. E así en amas cosas se ovo mal, e non erró menos en fazer aquello con que se quiere defender que en el primero error que cometió. Ca él primeramente perdió sus armas e desta fealdad non se pudiera escusar si non robara las agenas tomándolas de la sepultura; e dévese mucho agravar esto, ca non fueron estas armas que tomó de poco valor, mas son de grand reputación ca son armas

40 vençedoras e son armas consagradas a los dioses piadosos, e aun a este que acusamos fizieron ser varón fuerte. E si dixere él: 'tornélas a la sepultura', esto non es de oír, ca paresçe que se preçia por que non las perdió como las otras. E non puedes dezir, o acusado, que non caíste en la ley porque tornaste las armas, ca yo te juro por Hércules que así eres obligado a la pena como aquel que fiere a otro aunque el ferido sane de la

45 ferida, o como aquel que furta algo e después de tomado con el furto lo torna, nin deve ser dicho que por el vençimiento que fizo que le quitemos la pena, ca ya por la su virtud e vitoria dímosle gualardón. Por ende devemos usar de igualdad e justiçia, e pues onramos a este cavallero bivo como a varón fuerte porque se ovo bien en la batalla, así devemos vengar al cavallero finado la injuria que resçibió en ser tomadas las armas de su sepultura».

\section{En el libro quinto de las declamaçiones, la declamaçión primera de aquel que cortó la soga a otro en que se colgava, e acúsanle por ello como de malefiçio [V 1]}

El caso es este: un ombre andando por la mar ovo tormenta tanto que quebró el navío e él salió a nado desnudo; e después quemósele la casa e muriéronsele la muger e tres fijos que tenía. E él con la grand tristeza colgóse de un árbol por morir, e estando así colgándose acaesçió de pasar un ombre por ende e cortóle la soga e escapó. E así librado acusa al que le cortó la soga desto como de malefiçio.

10 Dize el acusado: «Quéxaste, o acusador, que perdiste tres fijos. Pluguiese a Dios que así los pudiera yo escapar de la muerte como escapé a ti. Olvida esto e bive, ca múdase el curso de la bien andança humanal, e ya acaesçió que el que una vez fue desterrado retornó e desterró a otros; los vençidos fuyen, los condemnados a muerte se asconden, los que andan en la mar e se les quebranta el navío nadan, e todo esto fazen por escapar

15 la vida. Dizes que perdiste la muger e los fijos e la fazienda; dime: ¿tú cuidavas que lo avías avido con tal condiçión que non lo perdieses? Juega la fortuna con sus dones, ca quita lo que dio e torna lo que quitó, e estonçe puede ombre más seguramente pelear con ella quando ella non tiene en qué le faga mal. Gneo Pompeyo aunque fue vençido 
en la batalla de Farsalia, pero después bivió. E si tú piensas que la muerte de tus fijos e

20 de tu muger es tu destruimiento e te quieres matar por eso, yerras, ca aún puedes bevir. Craso perdió non solamente lo suyo, mas aún lo del pueblo romano, pero por eso non dexó de bevir después algund tiempo. Todas las cosas te tiró la fortuna, mas dexóte la esperança, e si los ombres non toviesen esperança non avría alguno que una vez fuese vençido que tornase a pelear, mas muchos vençidos pelean después e vençen, nin avría

25 mercadero alguno que algund tiempo oviese mala dicha en las mercaderías que después tornase a mercar e vender, nin avría quien después de una vez quebrantado el navío cayese en la mar, aunque escapase, que más quisiese navegar. Pero vemos el contrario, e la esperança es el postrimero solaz que se ha en las cosas contrarias. Tú nadaste para que bivieses e yo ove misericordia de ti, nin pensé otra cosa de tus aventuras y

30 desventuras si non aquel peligro en que estonçe estavas, e cortéte la soga, nin se me membró del fuego de tus casas, nin de la muerte de tus fijos nin de tu muger, e aunque se me membrara non lo dexara de fazer por eso, pues que veía que después de todo aquello avías bivido. E paresçióme que non avías voluntad de te matar, pues escogiste lugar para ello por donde razonablemente devieras pensar que pasaría alguno que te estorvase».

Dize el acusador: «Quitara esta soga el señor de la heredad donde me yo colgava si quisiera, mas tú non tenías qué fazer en ello, ca non era tuya el árbol en que atara la soga. E non me quexo yo de la fortuna, ca ella dexávame morir, mas tú non me dexaste.

40 E por ventura dirás que me mate agora, mas esto es grande injuria, ca quando yo quería devía morir, non quando tú quisieres. Perdí la muger e los fijos e la fazienda; e non me dexó otra cosa la fortuna si non una soga con que me colgase, e tú aun aquella non me quisiste dexar. Yo escogí propios aparejos para la muerte, es a saber soledad e soga, la soledad porque es cosa conveniente para el ombre desaventurado, la soga porque era

45 cosa propia para me matar. E qualquier que por ende pasase non devía ál fazer si non mirar, e si fuese mi amigo, llorase, e si fuese mi enemigo oteáselo e callase. E aunque yo acuso a este, pero segund la calidad del fecho si yo venço más grave sería la sentençia contra mí que contra él, ca deven juzgar que yo me pueda libremente matar e que este acusado non me deviera nin deve vedar. E por non contar estas cosas e

50 desaventuras quería morir, e este estorvóme la muerte que era mi remedio. E si me queredes creer yo vos çertifico que quisiera la muerte con toda voluntad, salvo porque fue estorvada, ca non avía otro temor si non de bevir, porque la vida era a mí peor que la muerte, e yo muriendo acabava todos los tristes fados de mi casa. E en esto solo era más desaventurado que mi muger e fijos, porque moría después que ellos. E díme, o acusado, ¿para qué me escapavas de la muerte? Si lo fazías para que hedificase, cata mis casas quemadas; si para que navegase, otea mi nao quebrada; si para que criase mis fijos, míralos en la sepultura. E por çierto en tan malaventurada casa más bienaventurados fuistes, ¡o muger e fijos!, que yo, pues la fortuna vos dexó morir».

\section{Declamaçión sétima, de los tresçientos ombres que vinieron de noche a la çibdad e non los resçibió el capitán [V 7]}

En una çibdad avía una ley que dezía así: 'Non abra alguno las puertas de la çibdad de 5 noche. El capitán tenga soberano poderío en la guerra'.

El caso es este: tresçientos ombres de aquella çibdad fueron presos por los enemigos e 
soltáronse, e vinieron de noche a las puertas e llamaron. E el capitán non les quiso abrir e llegaron los enemigos que venían en pos ellos e matáronlos allí çerca las puertas. Después de acavada la guerra acusan al capitán como a dañador de la república porque non abrió a sus çibdadanos.

Dize la parte del capitan: «Non cuidé que eran míos, ca ellos bien sabían la ley que non se avían de abrir las puertas de noche; por ende razonablemente devía pensar que non eran de los nuestros, pues a tal ora venían. E si me dixere el acusador '¿por qué dexavas morir a tresçientos ombres?', puédole yo bien responder 'mas porque se dexaron ellos captivar por non morir'. E yo a estos aunque vinieran de día non los resçibiera, salvo si vinieran vençedores, e de noche aunque vinieran vençedores non les devía resçebir. Fui yo el otro día a la batalla para pelear e escreví estos tresçientos en el alarde, e non veo en ellos cosa que sea de loar salvo que fuyeron, nin ay cosa que dellos devamos desear salvo el cuento. Fuyendo non curaron de guardar las leyes de la guerra, e tornaron de noche para quebrantar las leyes de la çibdad. E el pueblo romano fue traído a grand apretura mucho por la batalla de Cannas tanto que se ovo de ayudar de los siervos, pero non curó de los cavalleros que estavan cativos, entendiendo que mejor defenderían la libertad los siervos a quien la davan de nuevo e nunca la avían avido que los cavalleros que la tovieron e la perdieron non la defendiendo bien. E yo te ruego que me digas, o acusador, cómo conosçeré yo de noche quál es enemigo o quál es de la çibdad, o qué señal me das tú para que conosca de noche las armas de los nuestros o de los contrarios. E yo creo bien que los enemigos estarían en alguna çelada para matar a estos que fuían e se entrar en la çibdad a vueltas con ellos si yo abriera las puertas».

Dize el acusador: «Mucho fue este capitan odioso destos tresçientos ombres, ca púsolos en mal lugar en la pelea por que fuesen presos. E porque desto non se pudiesen quexar non los resçibió en la çibdad quando fuyendo venían. ¿E qué maravilla es ser presos los ombres? Ca cativados fueron aquellos muy fuertes capitanes Régulo e Craso, e estos 35 cuitados ya a la fin non pedían ál si non que les diesen con qué se defendiesen, diziéndole: ‘¡capitán, échanos armas con que nos defendamos, ca esto por çierto non lo vieda la ley!'».

\section{Declamaçión segunda del libro segundo, del juramento que fizieron marido e muger [II 2]}

El caso es este: un marido e su muger juraron que si el uno dellos muriese que el otro se matase en pos dél. Acaesçió que el marido fue lueñe de la tierra e de allá embió uno que dixese a su muger que era muerto. La muger quando lo oyó echóse de una ventana abaxo. Tomáronla e curaron della e escapó. Su padre mandóle que se partiese de su marido, pues tal burla le avía fecho. Ella non lo quiso fazer e por esto deseredóla. Contienden sobre esta deseredaçión.

Dize la parte de la muger: « $i \mathrm{O}$ dioses inmortales, vosotros regides el linaje humanal con tanta sabiduria quanta devedes! Ca fezistes que aquel mandado que yo ove de la muerte de mi marido non me troxiese peligro de muerte, mas fiziese prueva çierta de mi amor. E lo que non partió la muerte quiere partir el suegro. Reprehéndeme mi padre porque dixe que quería morir por mi marido, mas non devo ser por ello reprehendida, ca tengo 
razón para lo fazer a enxenplo de otras dueñas que lo fizieron. Ca algunas ovo que se lançaron en el fuego donde quemavan los cuerpos de sus maridos. E algunas con su muerte escaparon la vida a sus maridos. E yo sin morir por aquella poca aventura que tomé así moça como só e biva seré nombrada entre aquellas nombradas e famosas que resçibieron por sus maridos muerte. Mi marido e yo avíamos continua contienda, ca dezía mi marido que non podría bevir si yo muriese, e dezía yo que tampoco biviría yo si él muriese. E como se suele fazer entre los que porfían, lo que dezíamos de palabra troxímoslo a juramento e juramos de non bevir el uno después del otro. E pues juramos de non nos partir por muerte, sin dubda nuestra voluntad fue de non nos partir en vida».

Dize la otra parte contra la muger: «Dizes tú, o muger, que non puedes dexar a tu marido. E díme: ¿quál cosa non puede fazer el que puede morir? E tu marido te enbió mandado falso de su muerte, mas poco le fallesçió de resçebir verdadero mandado de la tuya. E non te escuses diziendo que non puedes estar sin tu marido, ca bien puedes sin él

30 pasar, pues sofriste su absençia tan luengamente, nin te escuses con el juramento que feziste, ca suelta eres ya dél, pues por él te derribaste.»

\section{En el quinto libro, de la declamaçión quinta, de la casa del pobre que fue quemada por el rico su vezino con el árbol que delante ella estava [V 5]}

En una çibdad avía una ley que dezía así: 'Qualquier que fiziere daño a otro a sabiendas pague quatro tanto del daño que fizo; e el que lo fiziere por yerro non pague más de lo que monta en el daño'.

El caso es este: un rico tenía çerca de sí por vezino a un pobre, e el pobre tenía delante su puerta un árbol grande que empachava la vista a las ventanas del rico. E el rico rogóle que gelo vendiese para lo cortar, e el pobre non quiso, e el rico púsole fuego una

10 noche e quemóse el árbol e con él toda la casa del pobre. El rico quiere pagar por el árbol que quemó a sabiendas el quatro tanto, e por la casa non más del tanto. El pobre demándale el quatro tanto de todo.

Dize la parte del pobre contra el rico: «Despertéme con el sonido de la llama e lo 15 primero que fize, pregunté a los vezinos quién avía fecho aquello, ca yo non sabía que este rico lo fiziera fasta que me lo dixeron. E mi árbol tenía las ramas tan estendidas que cubrían toda mi casa, e este rico imaginó que pues non le dexava cortar por su ruego, quemarle. E por çierto muy desvergonçada maldad es codiçiar sin fin e ensañarse sin medida e entender que pues non me podía vençer con ruego, que devía vençer con

20 fuego. Ca bien entendio él que entre el rico e el pobre non ay diferençia quando el derecho se guarda. E dezidme, o ricos, ¿non vos paresçe que es razón que el pobre aya algund plazer en mirar sus árboles? Vosotros poseedes las heredades fasta la fin de los términos, e fenchides las çibdades con vuestras casas -tantas tenedes-, e metedes los montes e las aguas dentro de vuestros hedefiçios, ¿e el pobre non avrá si quiera algund plazer? ¿E paresçióte, o rico, que non avía cosa más plazentera a tus ojos que ver caída mi casa? E yo avía por muy grave perder un árbol, e fezísteme perder toda la casa. ¿E tú por razonable has que por que tú ayas deleyte nos quememos todos e tus ojos ayan plazer e la vista de tus ventanas sea más larga e más graçiosa quemando las casas de enderredor? Dirás tú que embargava mi árbol a tu vista; e díme, ¿qué maravilla hay en esto?: ca veemos que quando andamos por la calle algund embargo nos fazen los siervos 
que andan de una parte a otra, mas non los matamos por eso. E las paredes de las casas, con su altura, embárgannos la luz. E las lonjas e otros hedefiçios que se fazen para deporte, e las casas hedificadas en el suelo de las çibdades embárgannos de andar por donde queremos, mas non las derribamos por fazer más libre el andar. E so este árbol que me tú quemaste me deleitava yo pensando en las grandes huertas de los ricos. ¿E queredes saber qué tanto perdí yo en este fuego? Podédeslo bien considerar por esto solo, que mi enemigo, con quanta malenconia tenía de mí, dize que non quisiera que resçibiera yo tanto mal. E non pido agora cosa injusta, ca non demando ál si non que el daño que resçebí deste fuego se repare con el daño de aquel que lo puso.

40 E vosotros, o ricos, ¿avedes por razón que vuestras casas sean muy altas e tengan corredores fazia cada parte del çielo e sean calientes en el invierno e frías en el estío, de manera que las mudanças del año non ayan lugar en vuestras cámaras? Ponedes montes contra natura en lo alto de vuestras casas, e fazedes albercas para peçes tamañas que aína se navegarían. E la heredad en que en otro tiempo moravan pueblos e avían asaz que arar tiénela agora como alquería un vuestro labrador. E mayores términos tienen agora vuestros quinteros en que mandar que otro tiempo tenían los reyes. E a la mar arriedran ya de la tierra faziendo molles, ¿e non queredes que el pobre tenga un árbol delante de su puerta? E díme tú, o rico, ¿non sabías que tamaño es el poderío del fuego e que non se puede retener desque es començado e que es bastante para destruir las çibdades? ¿E non vees que de pequeños comienços se levantan grandes fuegos? Por ende, aunque alguna parte del daño non quisieras fazer, pero pues parte dello quisiste, tenido eres como si a sabiendas lo fizieras todo. Ca el que se quiere escusar diziendo que non lo supo, del todo lo deve non saber, ca sin dubda el que sabe parte en todo es tenido. Ca el que confiesa que puso fuego a la puerta o a alguna viga, bien se entiende

55 que toda la casa quemó, ca non ay alguno que lo ençienda todo, mas pone fuego en alguna cosa e dende se desparze por todas. E este árbol pues en mi casa estava, parte era della. Por ende, pues a sabiendas puso este rico el fuego en él, en toda la casa paresçe averlo puesto».

60 Dize la parte del rico: «Este árbol fazía toda mi casa doliente, ca cubríame todas las partes por donde podía venir aire sano, e rogué a este pobre e díxele: 'non te viene daño por que cortemos este árbol, ¿qué te aprovechan estos ramos que cuelgan fuera de tu casa, e aun en alguna parte de mi casa entravan e fazían daño e ya avían dañado algunas paredes? E bien sabedes quánta es la fuerça de los árboles, ca a las vezes rompen los muros.»»

\section{En el libro sesto, de la declamaçión sesta, de una muger que fue acusada de adulterio e de yervas. E llámase la declamaçión de la acusaçión de las yervas. [VI 6]}

5 El caso es este: uno tenía una muger e della una fija de hedad para casar, e dixo a su muger que quería casarla con un mançebo que le nombró. E la muger en oyéndolo dixo luego de priesa estas palabras: 'ante morrá que con él case'. Acaesçió que la moça murió ante de las bodas, e en su muerte ovo algunas señales por donde se presumió que moría de yervas. El padre por saber la verdad atormentó a una sierva suya e preguntóle 10 deste fecho. E la sierva dixo que non sabía cosa alguna de las yervas, mas que sabía que su muger cometía adulterio con aquel mançebo con quien el padre quería casar su fija. 
Agora este ombre acusa a su muger de las yervas e del adulterio.

Dize la parte del marido contra la muger: «Esta mi muger quando le dixe del casamiento

15 dixo: 'ante morrá que con él case'. E en quanto dixo 'morrá' paresçe bien que le dio yervas, e en quanto dixo 'ante que case' paresçe que cometía adulterio con él, e por estas palabras se me declaró el adulterio de mi muger después que fue fecho, e la muerte de mi fija ante que se fiziese. De dos malefiçios me querello yo, o juezes, e do vos dos mugeres que los demostraron. La una fue mi sierva, que dixo lo que era fecho; la otra

20 fue mi muger, que dixo non solamente lo fecho mas aun lo que se avía de fazer. E esta muger fizo malefiçio muy grande, ca cometió adulterio con su yerno e fue conglueça de su fija. ¡E quánt malaventurada es la casa en que el adulterio se allega por señal de otro malefiçio! Díxele quando le fablava del matrimonio que este mançebo era onesto e fermoso, e yo cuidava que le loava el yerno e loéle el que cometía adulterio con ella.

25 Digo vos que yo fui muy rudo e indiscreto en conosçer mis males tan tarde, ca aún non creía que era verdad lo de las yeruas e queriendo saber aquello supe lo del adulterio. Tornáronse en onras de mortuorios las bodas e la cama del axuar se tornó en lecho de muerte, e las alegres fachas que suelen ençender la noche del tálamo se tornaron en fuego en que se quemase el cuerpo de mi fija que començava ya a podresçer e estava

30 finchado con las yervas. ¿E qué otra prueva buscades, o juezes? Ca en este fecho concuerdan las señales con las palabras e los tormentos con las señales. E con tu palabra, o muger, concordaron los fados: tú dexiste 'morrá ante que case' e así se fizo. Ca vimos ya el cuerpo de mi fija desfecho e veyéndola muerta creímos lo que avía dicho su madre. E así perdí el yerno por adulterio e la muger por matar a su fija e a la fija por las yervas».

Dize la parte de la muger contra el marido: «De dos muy graves crímines acusa este a su muger, es a saber de adulterio e de dar yervas. El adulterio pruévalo solamente con testimonio de una sierva, e las yervas aun con la sierva non las prueva. E aquellas palabras que dize que dixo non se dixeron con deliberaçión, mas porque él le fablava el casamiento de su fija después de conçertado. Asañóse ella porque non fue primero rogada e saliéronsele aquellas palabras de la boca, mas ella non llora menos a su fija que el padre. E así clara está la razon por que dixo esta muger 'ante morrá que case con él', ca con el enojo que avía de non le aver ante dicho del matrimonio de su fija las dixo sin consideraçión, e non es maravilla salir verdad, ca acaesçe muchas vezes adevinar ombre en lo que dize por acaesçimiento».

\section{Declamaçión octava del libro terçero, del padre que fue acusado que levantara bolliçio en la çibdad [III 8]}

En Atenas avía una ley que dezía así: 'Quien fiziere ayuntamiento e bolliçio de gente

muera por ello'. El caso es este: quando fue entrada Olintho por Filipo rey de Maçedonia los de Atenas ordenaron que resçibiesen en su çibdad a todos los que viniesen de Olintho. E acaesçió que un ombre bueno viejo de Olintho vino a bevir a Atenas con un moço su fijo, e conbidólo a çenar un mal ombre de la çibdad, e estando çenando fablava de matarle el fijo, e el padre quando lo oyó fuyó, e el ombre que lo avía

10 conbidado detovo el fijo. E el padre començó a llorar delante la casa e al llanto dél ayuntóse gente e quemaron la casa e murieron diez mançebos que estavan dentro e el 
fijo del viejo. Agora acusan a este viejo porque fizo ayuntamiento de gente e bolliçio.

Dize la parte del acusado: «Mucho es de llorar si non dexan llorar al cuitado sus 15 miserias e dolores. Ca non es cosa que se pueda mandar que calle quien dolor tiene. Ayuntáronse muchos del pueblo a esto, e aquellos que se ayuntaron querellávanse de los mançebos que estavan dentro en la casa diziendo los malefiçios que avían fecho. E uno dezía 'aquel forzó a mi fija', otro dezía 'aquel desonró a mi muger'. Témome, o fijo, que buscándote entre los muertos tope con los huesos de algund malfechor de aquellos con quien te quemaste. Dezidme, o varones: ¿dónde es la fe de Atenas, dónde son las manos diestras con que solíades conbidar a los huéspedes? E quando fue tomada mi çibdad de Olintho dixe a mi fijo: 'tomados somos, o fijo; fuyamos mientra podemos e vayamos a lugar donde Filipo non nos pueda fazer mal. Pero non resçebimos tanto mal de Filipo como aquí avemos resçebido. Acúsanme agora diziendo que llore, ¡como si oviese çesado de llorar despues que Olintho fue tomada!; lo qual non es así, ca siempre continué el llorar. E acúsanme que fui poderoso para ayuntar e bollesçer el pueblo en esta çibdad donde non pude defender a mi fijo. E por çierto non se dize ayuntamiento nin bolliçio de pueblo por se allegar muchos ombres a un lugar, mas estonçe se dize ayuntamiento e bolliçio quando vienen llamados e prestos para seguir a un capitán. Ca

30 si en una calle se ayuntan los que pasan o están pocos ombres ayuntados por eso non se dize ayuntamiento, mas quando todo el pueblo o grand parte dél se ayunta o se parte en vandos e partes la çibdat. Ca este vocablo ayuntamiento e bolliçio de sí mesmo significa muchedumbre de gente que se allega deliberadamente para fazer algo. Mas en este caso aquellos que primero vinieron pocos eran, mas después allegáronse otros e non venían a mí, mas venían a ver el fuego, e el pueblo quiso más mirar aquel fuego que matarlo. E la ley que dezides non manda dar pena a aquel por cuya causa se faze el ayuntamiento e bolliçio, mas a aquel que lo faze. E yo non ove tanta voluntad de me vengar de los malfechores que quisiese perder mi fijo en aquel fuego, mas non pude más, ca rogué al pueblo que non quemase la casa e non quisieron».

Dize la otra parte: «¿Para qué era menester fazer ayuntamiento de gente?, pues todas las leyes son escritas para vengar las injurias. E quando la mucha gente es ayuntada non guarda templamento en lo que ha de fazer. E pudiera muy bien ser que con el fuego de aquella casa se quemara toda la çibdad».

\section{Raptor duarum [I 5]}

Rapta raptoris aut mortem aut indotatas nuptias optet. Vna nocte quidam duas rapuit. Altera mortem optat, altera nuptias.

«Stupro accusatur, stupro defenditur; cum altera rapta litigat, alteram aduocat. Vindicate, patres, fortior publicae disciplinae seueritas surgat: iam binae rapiuntur! Coit populus uelut publico metu territus et uix credens duos fuisse raptores. Alteram iniuriae rapuit, alteram patrocinio. Perieras iam, raptor, nisi bis perire meruisses». «Si te ante

10 rapuisset et nuptias optasses, deinde hanc uitiasset antequam nuberes, negares illum iubente rapta debere mori? Nihil amplius raptori praestare potes quam ne tua lege pereat; contra alienam legem nullum ius habes. Tu raptori praestas, ut illum ipsa non occidas; non potes praestare, ne quis occidat». 
15 Altera pars: «Inter pares sententias, mitior uincat. Refer Virginiam, dic Lucretiam; plures tamen Sabinae sunt. Contumeliosum mihi erit te dignam uideri, in cuius honorem homo occidatur, me dignam non uideri, in cuius honorem homo seruetur».

\section{Phidias amissis manibus [VIII 2]}

Sacrilego manus praecidantur. Elii ab Atheniensibus Phidian acceperunt, ut his Iouem Olympium faceret pacto interposito, ut aut Phidian aut centum talenta redderent.

5 Perfecto Ioue Elii Phidian aurum rapuisse dixerunt et manus tamquam sacrilego praeciderunt; truncatum Atheniensibus reddunt. Petunt Athenienses centum talenta. Contradicitur.

«Iam Phidian commodare non possumus. Tunc demum illa maiestas exprimi potest, cum animus opera prospexit, manus duxit; ante sibi quam operi Iouem fecit. Sacrilegi uos estis, qui praecidistis consecratas manus. Primum sanguinem deus sui uidit artificis. Testor Iouem, proprium iam Phidiae deum. Ars alios in miseria sustinet, te miserrimum fecit. Paciscendum Phidian manus fecerant. Sine eo Phidian nos recepturos putatis, sine quo uos accepturi non fuistis? Commodauimus qui facere posset deos; recepimus qui ne adorare quidem possit. Non pudet uos Iouem debere sacrilego? Superest homo, sed artifex periit. Poenam nobis Phidiae, non Phidian redditis. Manus, quae solebant deos facere, nunc ne homines quidem rogare possunt. Talem fecit Iouem, ut hoc eius opus dii esse ultimum uellent. Manus commodauimus, manus reposcimus. Elius est testis, Elius accusator, Elius iudex; Atheniensis tantum reus. Inuoco deos, et illos quos fecit Phidias et illos quos facere potuit. Recepimus Phidian, confiteor, si possumus commodare».

Pars altera: «Habuimus aurum olim sacrum, habuimus ebur; sacrae materiae artificem quaesiuimus. Disposueramus quidem, ut aliis quoque templis simulacra Phidias faceret, sed non erat tam necesse ornare deos quam uindicare».

\section{Crux serui uenenum domino negantis [III 9]}

Aeger dominus petiit a seruo, ut sibi uenenum daret; non dedit. Cauit testamento, ut ab heredibus crucifigeretur. Appellat seruus tribunos.

«Lex Cornelia, te appello: ecce heres iubet quod tu uetas. Ne quis illum displicuisse domino putet, tunc huic parari iussit crucem, cum sibi uenenum. Plura serui crimina confitemur: intempestiuas potiones, inutiles cibos desideranti negauit; quid enim ille non uoluit, qui uenenum petiit? 'Maluit crucem pati quam mereri.' Si uincitur, periturus est, si non uincitur, seruiturus ei, a quo in crucem petitur. Ex altera parte lex est, ex altera testamentum, crux utrimque. Furiosum seruus sine causa uoluit occidere. Quaeritis insaniae argumentum? Et se uoluit occidere. 'Seruo' inquit 'tribuni non possunt succurrere.' Seruum regem habuimus, seruo indice patefacta est Bruti liberorum cum Tarquino coniuratio. Ergo nihil interest, uenenum domino dederit aliquis an

15 negauerit? Etiam ubi remedium est mori, scelus est occidere. Tam cito uos de uita domini seruum desperare uultis quam heredem? Mortem si supplicium putas, quid 
rogas? Si beneficium, quid minaris? Venenum quisquam obicit nisi datum? Vllum tu finem facies tribuniciae potestati, quam populus Romanus, ut ipse plurimum posset, plus ualere quam se uoluit? Venenum habere scelus est tam magnum quam dominum occidere».

Pars altera: «Mori uolens elegit huic ministerio nequissimum seruum, audacem, infestum sibi. Ille non saluti consuluit domini, quem uidebat insanabili morbo tabescere, sed tormenta eius extendit. Seruus erilis imperii non censor est sed minister. Agatur de iure testamentorum, quorum interiit omnis potestas, si uiui imperia neglexerint, mortuorum tribuni. Ita ne fur ei praeferatur non morieris domini arbitrio, morietur dominus tuo».

\section{Armis sepulchri uictor [IV 4]}

Sepulchri uiolati sit actio. Bellum cum esset in quadam ciuitate, uir fortis in acie armis amissis de sepulchro uiri fortis arma sustulit. Fortiter pugnauit et reposuit. Praemio accepto accusatur sepulchri uiolati.

«Arma uix contigeram; secuta sunt. Haec si sumo, arma sunt; si relinquo, spolia. Vidisses uere uiolari sepulchrum, si illo uenisset hostis. Vterque quod alteri deerat commodauimus: ille uiro arma, ego armis uirum. Res publica multum consecuta est, uir

10 fortis nihil perdidit. Necessitas est quae nauigia iactu exonerat, necessitas quae ruinis incendia opprimit; necessitas est lex temporis. Quicquam non fit legitime pro legibus? Melius cum ipso sepulchro actum est, in quo notiora sunt iterum arma uictricia. Pro re publica plerumque templa nudantur et in usum stipendii dona conflamus».

15 Pars altera: «Reum habemus in proelio inertem, in fuga audacem, turpem non minus patrocinio quam crimine: arma sua perdidit; hoc excusare non poterat, nisi aliena rapuisset. Aliena rapuit; hoc excusare non poterat, nisi sua perdidisset. Arma uictricia, arma consecrata diis manibus, arma quae te quoque fecerunt uirum fortem. 'Reposui' inquit 'arma'; gloriatur, quod non et illa perdiderit. 'Non teneor lege, quia reposui.' Tam

20 teneris hercule, quam qui uulnerauit aliquem, licet uulnus sanauerit, quam qui subripuit aliquid, licet reddiderit deprehensus. Non est hoc illi crimen propter uirtutem donandum: iam gratiam uirtuti rettulimus; praemium consecuta est. Aequos esse nos conuenit: unum uirum fortem honorauimus, alterum uindicemus».

\section{Laqueus incisus [V 1]}

Inscripti maleficii sit actio. Quidam naufragio facto, amissis tribus liberis et uxore incendio domus suspendit se. Praecidit illi quidam ex praetereuntibus laqueum. A liberato reus fit maleficii.

«'Tres' inquit 'liberos perdidi'; utinam et illos seruare potuissem! Viue; mutantur uices felicitatis humanae: proscriptus aliquando proscripsit. Victi fugiunt, proscripti latent, naufragi natant. 'Amisi' inquit 'uxorem, liberos, patrimonium'; tu putabas te ea condicione accepisse, ne perderes? Ludit de suis Fortuna muneribus et quae dedit aufert, 
quae abstulit reddit, nec umquam tutius est illam experiri quam cum locum iniuriae non habet. Cn. Pompeius in Pharsalia uictus acie uixit; mortem tuorum maius tu tuum putas esse naufragium? Crassus uixit, et non priuatas perdiderat sed publicas opes. Omnia tibi Fortuna abstulit sed spem reliquit. Tolle spem hominibus: nemo uictus retemptabit arma, nemo infeliciter experta negotiatione alios appetet quaestus, nemo naufragus uiuet. Spes est ultimum aduersarum rerum solacium. Vt uiueres, natasti. Miseritus sum nec in te amplius quam periculum cogitaui; non attendi incendium, non orbitatem, aut, si attendi, memineram te post illa uixisse. Non uisus est mihi moriendi animum habere: elegerat locum, in quo interpellari posset».

Pars altera: «Tollat fundorum dominus aliena arbore suspendo laqueum. De fortuna nihil queror: mori permittit. 'Nunc' inquit 'morere'; iniuria est, ut, qui meo arbitrio debui, tuo moriar. Amisi uxorem, liberos, patrimonium; fortuna mihi nihil praeter laqueum reliquit, iste nec laqueum. Sumpsi instrumenta mortis solitudinem et laqueum, alterum aptum morituro, alterum misero. Quisquis interuenis, si amicus es, defle, si inimicus es, specta. Cum a me iste accusetur, grauiorem de me quam de reo ferte sententiam: ego ut moriar, iste ne prohibeat. Ne haec narrarem, mori uolui. Praecidit remedium meum. Si qua est fides, non enataui sed eiectus sum. Nihil iam timebam nisi uiuere. Domus meae fata claudo, nullo miserior quam quod ultimus morior. Cui me uitae reseruas? Vt aedificem? Aspice incendium. Vt nauigem? Aspice naufragium. Vt educem? Aspice sepulchrum. In tam calamitosa domo feliciores fuistis, uxor et liberi: uobis mori contigit».

\section{Non recepti ab imperatore [V 7]}

Nocte in bello portas aperire non liceat. Imperator in bello summam habeat potestatem. Trecenti ab hoste captiui ad portas nocte uenerunt; imperator non aperuit. Ante portas occisi sunt. Imperator post uictoriam reus est laesae rei publicae.

«Non putaui meos: nouerant legem. 'Cur', inquit, 'trecenti perierunt?' Immo cur, ne perirent, capti sunt? Hos ego interdiu non recepissem nisi uictores, noctu ne uictores quidem. Procedens postridie in proelium pugnaturis ostendi trecentos, in quibus nihil

10 laudari potest praeter fugam, nihil desiderari praeter numerum. Fugiunt, ut leges relinquant, reuertuntur, ut tollant. Populus Romanus Cannensi proelio in summas redactus angustias, cum seruorum desideraret auxilia, captiuorum contempsit et credidit eos libertatem magis tueri posse, qui numquam habuissent quam qui perdidissent. Nocte quomodo hostem ciuemque distinguam? Quam mihi das notam ut arma cognoscam?

15 Credo in insidiis hostes fuisse, ut exclusos occiderent, sequerentur admissos».

Pars altera: «Infestus illis trecentis fuit, iniquo collocauit loco. Hoc ne agi possent, non recepit. Capti sunt fortissimi duces, Regulus, Crassus. Haec postrema rogantium uox erat: 'mitte arma! Certe hoc lex non uetat.'»

\section{De uiro et uxore [II 2]}

Vir et uxor iurauerunt ut si quid alteri accidisset, alter moreretur. Vir peregre profectus est; misit nuntium uxori, qui diceret se decessisse. Vxor se precipitavit. Recreata iubetur 
a patre uirum relinquere; non uult. Abdicatur. Contradicit.

«Dii immortales, qua debetis prudentia humanum genus regitis; effecistis, ut illud periculum non amantis esset sed experimentum. Hos diuidere uult socer, quos nec mors quidem diuidet? 'Moriar', inquit, 'habeo causam et exemplum. Quaedam se maritorum rogis ardentibus miscuerunt, quaedam anima redemerunt maritorum salutem.

10 Sollicitudine breui inter has puella uiua numeratur. Assiduae contentiones erant: 'sine te uiuere non possum'; 'immo ego, sine te'. Qui certantium exitus solet esse, iurauimus. Hic animus sine dubio iurantium fuit, ut uiui non diducerentur, cum illud quoque cauerent, ne morte diuiderentur».

15 Altera pars: «'Non possum', inquit, 'relinquere uirum'. Quicquam non potest, quae mori potest? Paene, dum falsae mortis nuntium misit, uerae recepit. Potes sine uiro pati: peregrinationem eius tulisti. Iureiurando iam liberata es casu proximo».

\section{Domus cum arbore exusta [V 5]}

Qui sciens damnum dederit quadruplum soluat, qui inscius simplum. Diues pauperem uicinum rogauit, ut sibi arborem uenderet, quam sibi dicebat obstare; pauper negauit.

5 Diues incendit platanum, cum qua et domus arsit. Pro arbore pollicetur quadruplum, pro domo simplum.

«Excitatus flammarum sono uicinorum primo fidem imploraui. Arbor ramis excurrentibus totam domum texerat. 'Non potest exorari; incendatur.' Est hoc

10 impotentiae, sine fine concupiscere, sine modo irasci. 'Non potest expugnari precibus; expugnetur ignibus.' Nihil inter me et pauperem interest, si iure agamus. Liceat et pauperem gaudere prospectu. Vos possidetis agros usque ad urbium fines urbesque domibus impletis, intra aedificia uestra undas ac nemora comprehenditis. Nihil laetius occurrit oculis tuis quam ruinae meae. Domum perdidi, qui carere ne arbuscula quidem

15 poteram. Deliciis tuis, diues, ardebimus? Oculis uoluptas in incendio quaeritur et prospectus ignibus relaxatur. 'prospectui obstabat.' Quid? Inambulantibus nobis non obstant seruorum cateruae? Excitati in immensam altitudinem parietes lucem non impediunt? Infinitis porrectae spatiis ambulationes et urbium solo aedificatae domus non nos prope a publico excludunt? Sub hac arbuscula imaginabar diuitum siluas.

20 Quantum perdidi, quem fatetur iratus inimicus plus perdidisse quam uoluit! Non iniquum postulo: eius damno desinat incendium, cuius consilio coepit».

«Scilicet ut domus ad caelum omne conuersae brumales aestus habeant, aestiua frigora, et non suis uicibus intra istorum penates agatur annus, agunt in summis culminibus mentita nemora et nauigabilium piscinarum freta. Arata quondam populis rura singulorum nunc ergastulorum sunt, latiusque nunc uillici quam reges imperant. Maria proiectis molibus submouentur. Nesciebas, quanta sit potentia ignium, quam irreuocabilis, quemadmodum totas absumat urbes, quam leuibus initiis oriantur incendia? Etiamsi partem damni dare noluisti, si tamen uoluisti partem, in totum, quasi prudens dederis, tenendus es; ex toto enim noluisse debet qui imprudentia defenditur. Si

30 fatereris te scientem ianuam incendisse, si unum tignum, puto, tota domus intellegeretur ex parte, nec enim quisquam omnia incendit sed unam aliquam rem, ex qua surgat in omnia se sparsurus ignis. Atqui pars domus est arbor, quae in domo est». 
Pars altera: «Pestilentem mihi faciebat domum arbor; caelum omne, per quod salubris spiritus uenire posset, obduxerat. Rogaui pauperem et dixi: nihil tibi nocet arbor recisa, mihi plurimum non recisa. Quid ad te illi rami pertinent, qui extra domum sunt? Quasdam partes domus meae rami premebant, iam etiam quosdam parietes mouerant. Scitis, quanta sit uis arborum; muros discutiunt».

\section{Adultera uenefica [VI 6]}

Veneficii sit actio. Quidam, cum haberet uxorem et ex ea filiam nubilem, indicauit uxori, cui eam collocaturus esset. Illa dixit: 'celerius morietur quam illi nubat!' Decessit puella ante diem nuptiarum dubiis signis crudelitatis et ueneni. Torsit ancillam pater, dixit illa nihil se scire de ueneno sed de adulterio dominae et eius, cui collocaturus filiam erat. Accusat uxorem ueneficii et adulterii.

«'Morietur': teneo ueneficam; 'celerius quam nubat': teneo adulteram. 'Morietur':

10 factum est; 'celerius quam nubat': factum est. Adulterium deprehendi serius quam factum est, ueneficium antequam fieret. Duo crimina ad uos detuli et duas indices: altera dicit quod factum est, altera etiam quid futurum sit. Generi adultera, filiae paelex. Quam infelix domus est, in qua adulterium argumentum est! Dixi: 'honestus est', dixi: 'pulcher est'; dum laudo generum, commendaui adulterum. O me tardissimum in malis meis! Veneficium ne denuntiatum quidem credidi, adulterium in ueneficio demum deprehendi. Versae sunt in exequias nuptiae mutatusque genialis lectus in funebrem, subiectae rogo felices faces. Profertur putre corpus et uenenis tumens. Quid ultra quaeritis? Verbis signa, signis tormenta conueniunt». "Ad uocem tuam fata conueniunt: 'morietur antequam nubat'; factum est, uidimus fluens corpus et in cadauere illius materna uerba credidimus. Generum adulterio perdidi, uxorem parricidio, filiam ueneno».

Pars altera: «Duo grauissima crimina obiecit, adulterium et ueneficium; adulterium ancilla teste, ueneficium ne ancilla quidem. Cum indignaretur se non rogatam, exciderunt illi uerba, quae non minus quam pater filiam luget. At quare dixisti: 'celerius morietur quam illi nubat'? Verba dolori parum considerata exciderunt, ut est saepissime fortuita diuinatio»».

\section{Olynthius pater reus concursus [III 8]}

Qui coetum et concursum fecerit capitalis sit. Victa Olyntho cum filio adulescente Olynthius senex Athenas uenit. Athenienses omnibus ciuitatem Olynthiis decreuerunt.

5 Inuitatus ad cenam ab adulescente luxurioso cum filio uenit. Ibi cum de stupro filii mentio esset, pater profugit, adulescens retentus est. Pater flere ante domum coepit; incensa est domus, decem adulescentes perierunt et filius Olynthii. Accusatur pater, quod coetum concursumque fecerit.

10 «Misero si flere non licet, magis flendum est. Imperari dolori silentium non potest. Fuerunt ex populo, qui dicerent: 'hic meum filium, hic meam corrupit uxorem'; suum 
quisque illo et ignem attulit et dolorem. Timeo, fili, ne, dum te quaero, in ossa raptoris alicuius incidam. Vbi Athenarum fides, ubi hospitales inuicem dexterae? 'Capti', inquam 'fili, sumus; dum licet, fugiamus, sed, tamquam a Philippo, pariter.' Apud

15 Philippum certe uiri fuimus. Lacrimae meae uocantur in crimen, quasi, ex quo Olynthos capta est, flere desierim! Tantus scilicet sum, ut in ea ciuitate populum concitare potuerim, in qua filium seruare non potui. Non, quotiens conuenerunt in aliquem locum plures, coetus et concursus est, sed quotiens conuocati, quotiens parati quasi ad ducem suum concurrerunt; non si una uicinia coit aut transeuntium paucorum numerus affluxit,

20 sed ubi totus aut ex magna parte populus, ubi diuisa in partes ciuitas. Coetus multitudinis magnae nomen est coeuntis ex consensu quodam; at illic initio pauci fuerunt, deinde reliqui non ad me conuenerunt sed ad incendium, quod tamen populus spectare maluit quam extinguere. Lex non eum punit, propter quem coetus factus est, sed eum, a quo factus est. Non mihi tanti ultio fuit, ut amittere filium uellem; et temptaui populum rogare nec potui».

Pars altera: «Quid coetu opus est? Sunt scriptae ad uindictam iniuriarum omnium leges. Mota semel multitudo modum non seruat. Ardere illo incendio ciuitas potuit» 


\section{APARATO CRÍTICO}

\section{Siglas}

\section{Texto romance}

$M \quad$ Madrid, Biblioteca Nacional 6765

$S \quad$ Salamanca, Biblioteca de la Universidad 201

$N \quad$ Madrid, Biblioteca Nacional 6962

E San Lorenzo de El Escorial, Biblioteca del Real Monasterio T.III.6

$O \quad$ Madrid, Biblioteca Nacional 8188

$P \quad$ Madrid, Biblioteca Real, II/3072

e $\quad$ Cinco libros de Séneca, Sevilla 1491

W consensus omnium codicum excepto notato

\section{Texto latino}

$\begin{array}{ll}M_{c} & \text { Montpellier, Montepessulanus H 123 } \\ P_{c} & \text { Paris, Bibliothèque nationale, Parisinus latinus 7836 } \\ S_{c} & \text { Paris, Bibliothèque nationale, Parisinus latinus 16592 } \\ a & \text { Sankt Gallen, Biblioteca coenobii Admuntani, 221 } \\ b & \text { Berlin, Staatsbibliothek, Diez. C fol. 4 } \\ g & \text { Paris, Bibliothèque nationale, Parisinus latinus 8542 } \\ m & \text { Paris, Bibliothèque nationale, Parisinus Mazarinaeus 1261 } \\ l & \text { Città del Vaticano, Vaticanus latinus 1773 } \\ n & \text { editio princeps (Nápoles 1475) } \\ p & \text { Paris, Bibliothèque nationale, Parisinus latinus 8717 } \\ r & \text { Città del Vaticano, Vaticanus Reginensis 1637 } \\ \text { A } & \text { Madrid, Biblioteca Nacional 10238 } \\ T & \text { San Lorenzo de El Escorial, Biblioteca del Real Monasterio S.II.3 } \\ \text { Håk } & \text { L. Håkanson (Leipzig, 1989) } \\ \text { Müll } & \text { H. J. Müller (Viena, etc., 1887) } \\ \text { Bs } & \text { Conradus Bursian } \\ F b & \text { Nicolaus Faber } \\ F r o b & \text { editio Frobeniana (Basilea, 1515) } \\ \text { Gr } & \text { Johannes Fredericus Gronov } \\ \text { Herv } & \text { editio Hervageniana (Basilea, 1557) } \\ <\ldots> & \text { additiones codicum singulorum }\end{array}$

\section{Abreviaturas}

a.c. ante correctionem

add. addit, addunt

om. omittit, omittunt 


\section{TEXTO CASTELLANO}

\section{5}

1 deest $E$ • forçador e del robo $\Omega$ : del robo e del forçador $S \mathbf{4}$ alguno $M S O P$ : alguna $N e \mathbf{5}$ en ... ley $M S$ : una ley avia en una çibdat $N O P e \bullet$ puede $\Omega$ : pueda $N \mathbf{6}$ ella le de $M N e$ : ella de $S$ : le de ella $O \bullet$ alguno $\Omega$ : alguna $N 7$ en esta $\Omega$ : desta $P \bullet$ uno $M S$ : un ombre $N O P e \bullet$ en una noche $\Omega$ : una noche $e \mathbf{8}$ demanda $\mathrm{om}$. $O \bullet$ sin que ella le de dote alguno post marido add. $M$ 10 dize ... maten om. $O \cdot$ de fornicaçion $\Omega$ : por fornicador $O 11$ forçosa fornicaçion $S O$ : forçada fornicaçion $M N e$ : fornicaçion forçosa $P \cdot$ forçada $\Omega$ : forçosa $P 12$ tal malefiçio $\Omega$ : tan mal fecho $N 13$ levantese $M N S P$ : levantase $O e \cdot$ cruo $\Omega$ : fuerte $P \bullet$ publica MNOe : republica $S$ : om. e 14 tal malefiçio $M N$ : tan mal fecho $S: \tan$ gran malfecho $O: \tan$ mal malefiçio $P e \cdot$ e espantado $M S N P$ : espantado Oe 15 un publico $\Omega$ : una publica $P \cdot$ han de creer $M S$ : ha de creer $N e$ : de creer $O$ : de creçer $P 16$ dos forçadores $N O P e$ : dos fuerças $M S 17$ para ... defendiese $\Omega$ : porque lo defendiese $e \cdot$ matarian $M S N O$ : mataran Pe $\mathbf{2 1}$ otra om. $P 22$ dirias $\Omega$ : pidieras $O \bullet$ tu om. $P \mathbf{2 3}$ otra cosa om. $O \cdot \mathbf{2 5}$ a tu forçador $S O P e$ : al forçador $M N \mathbf{2 6}$ causa $\Omega$ : cosa $P 28$ dos iguales $M N$ : dos cosas iguales $P e \cdot$ mas mansa $M S N P$ : mas blanda $O$ : una mansa $e \mathbf{2 9}$ a Virginia $\Omega$ : averigua $e \cdot \operatorname{recontar} M S N O$ : retornar $P e \bullet$ muchas fueron mas $N$ : muchas fueron $M S$ muchas mas fueron $O P e \mathbf{3 0}$ seas avida $M N O e$ : fueses avida $P \bullet$ que maten ... que por om. $e$

\section{2}

1 deest $E \cdot$ sacrilegio $M N O e$ : sacrilego $S P 3$ como ... prestado a $\Omega$ : llamase esta declamaçion la de $e \bullet$ pidieron $\Omega$ : demandaron $P \bullet$ muy $M S$ : mucho $N O P e 7$ dezia $M S N O$ : dize $P e \bullet$ cometiere $M S N e$ : fiziere $O P \bullet$ sacrilegio $\Omega$ : sacrilego $P 9$ sotil $\Omega$ : bueno $P 11$ lo tornasen $\Omega$ : gelo tornasen $P \mathbf{1 2}$ despues que $\Omega$ : desque $N \bullet$ lo . . acabado $M S$ : lo ovo acabado $N O P$ : ovo acabado $e \cdot \operatorname{los}$ elios dixeron $\Omega$ : dixeron los elios $P 13$ a sacrilego MSOe : a sacrilegio $N$ : por sacrilego $P 14$ contradizenlo $M S$ : contradizen NOPe 16 dizen los de Atenas om. $O \bullet$ non podemos $\Omega$ : non podriamos $O \mathbf{1 7}$ fazer bien $M$ : bien fazer $S N O P$ : fazer $e \cdot$ imagines de qualquier $M S N$ : imagen de qualquier $O$ : imagines e a qualquier $P$ : imagines e qualquier $e \bullet$ lo pensava ... lo obrava $M S$ : la pensava ... la obrava $N$ : le pensava ... lo obrava $O$ : pensava ... los obrava $P$ : los pensava ... los obrava $e \mathbf{1 9}$ ante om. $P \bullet$ podra $\Omega$ : podria $e \mathbf{2 0}$ sacrilegos $\Omega$ : sacrilegios $O \bullet$ cortastes $\Omega$ : cortastestes $P \bullet \operatorname{dios}$ om. e $\mathbf{2 1}$ sangre $\Omega$ : de sangre $O \bullet$ fago testigo $\Omega$ : te fago por testigo $O 22$ e $\Omega$ : o $S \mathbf{2 3}$ menesteres $\Omega$ : menguas $e \bullet$ tu om. $P \bullet$ fizo $M N O$ : haze $P e \bullet$ e cuitado $\Omega$ : cuitado $O \mathbf{2 4}$ por las manos de Fidias $S N O P$ : por las manos Fidias $M$ : las manos de Fidias $e \cdot$ tornasen $\Omega$ : cortasen $P 27$ tornadesnos : MNOe : tornades $S$ : tornastesnos $P 28$ esto $M S O$ : este $N P e \bullet$ que es $M N P$ : que este fue $S$ : que fue $O e \bullet$ sacrilego $M P e$ : sacrilegio $S N O \bullet$ non es asi, antes lo ante devedes $a d d$. $O 29$ vos $\Omega$ : vosotros $e \mathbf{3 0}$ mostradesnos $N P e$ : mostrandonos $M S$ : mostrandovos $O 32$ esta $M$ : esto $S N P$ : este $O e \bullet$ las ... prestamos om. $O \bullet$ manos $\Omega$ : mas $O 34$ que ... Fidias om. $S 35$ resçibieramos : resçebimos $M N P e$ : resçibiremos $O \mathbf{4 0}$ otros $M S N O: \operatorname{los}$ otros $P$ : nuestros $e \cdot$ Fidias ante en otros templos $S \cdot$ imagines ante fiziese $S \mathbf{4 1} \operatorname{los} \operatorname{dioses} \Omega: \operatorname{los} \operatorname{dios} O \bullet$ es $\Omega$ : era $P$

\section{9}

1 deest $E \bullet$ e om. Ne 3 su siervo $M S N P$ : siervo $O$ : siervo suyo $e \cdot$ avia querido $M N O$ : queria $S$ : ha querido $P$ : quiso $e \cdot \mathbf{5}$ la de la cruz $M S O e$ : la declamaçion de la cruz $N$ : de la cruz $P \mathbf{6}$ 
yervas $\Omega$ : yerras $e \mathbf{7}$ avia que post señor $a d d$. $O \bullet$ su $\Omega$ : un su $e \mathbf{8}$ e el ... fazer om. $e \mathbf{9}$ que ... cruçificar $M S$ : que le fiziesen cruçificar $N O P e \cdot$ querellase $\Omega$ : querellandose $O 14$ fizo $\Omega$ : fiziese $O \bullet$ señor $^{2} \Omega$ : rey $P \mathbf{1 5}$ quando $\Omega$ : por quanto $O \bullet$ mesmo om. $S \bullet \operatorname{los} M S N O$ : lo $P$ e $\mathbf{1 8}$ demandava $\Omega$ : mandava $P \bullet$ respondere $\Omega$ : respondote $O 20$ ha ... cruçifiquen $\Omega$ : cruçificanlo $O 21$ es el MSNe : el $O$ : esta el $P \mathbf{2 3}$ salvo $M S$ : si non NOPe $\mathbf{2 4} \operatorname{dira} \Omega$ : $\operatorname{diria} S \mathbf{2 5}$ a un siervo om. Pe $\mathbf{2 6}$ con $\Omega$ : e $S \mathbf{2 8}$ la muerte $\Omega$ : ella $O \mathbf{2 9}$ algunas cosas e trabajos $M S$ : algunos trabajos NOPe $\mathbf{3 0}$ desesperase $\Omega$ : se desesperase $P \bullet$ de $\Omega$ : a $O \mathbf{3 1}$ desespera $\Omega$ : desesperase $e 33$ alguno $M e$ : ninguno $N O P \bullet$ otro $\Omega$ : otros $e \mathbf{3 4}$ acortar $\Omega$ : cortar $e \mathbf{3 5}$ quiso ... mas que om. $O 38$ dize... parte $o m$. $O \bullet$ morir ... rebelde $o m$. $P \bullet$ el señor ... rebelde $o m$. $e \bullet$ siervo $M$ : su siervo SNOP 39 diese $\Omega$ : diesen $N \bullet$ porque $\Omega$ : que $e \mathbf{4 1}$ durase $M S N O$ : le durase $P e \cdot$ el siervo ... mandamientos om. $O 42$ emendador $\Omega$ : ha medido $O 43$ todo el om. e 44 mandan $M S N$ : mandasen $O P e \mathbf{4 5}$ fue $M N P e$ : fuera $S O \bullet \tan$ om. $S \mathbf{4 6}$ morir nin bevir el $M S$ : morir el $N P e$ : morir $O$

\section{4}

3 proponen $M N E P$ : propone $S O e \cdot$ acçion $M N E O e$ : adiçion $S$ : quistion $P \bullet \operatorname{del} \Omega$ : de $e \mathbf{5}$ el caso es este om. Oe $\mathbf{9}$ buen cavallero $\Omega$ : cavallero bueno $P \mathbf{1 1}$ a este cavallero $\Omega$ : a este $e \mathbf{1 2}$ gualardon $M E O P$ : galardon $S N e \bullet$ segund $\mathrm{om}$. $O \bullet$ acusanle $M S N E O$ : recusanle $P e 16$ por çierto $\Omega$ : çierto $S \cdot$ dexara $\Omega$ : yo dexara $O \bullet$ armas mas fueran om. $O 17$ despojo MSOPe : espojo $N E \bullet$ aquello $\Omega$ : aquella $e \cdot$ fuera $\Omega$ : fue $P \mathbf{1 8}$ ofensa $\Omega$ : ofenso $e \bullet$ segunda ante sepultura $a d d$. $P \bullet$ llegaran los enemigos $M S$ : llegara el enemigo NEOPe 19 prestado $M N E e$ : prestido $S$ : emprestado $O$ : prestamo $P 21$ cuerpo para pelear $N E O P e$ : cuerpo $M S \mathbf{2 2}$ perdio en ello $O$ : perdio por ello $S$ : perdio $M N E P e \mathbf{2 3}$ que por tamaña $M N E e$ : que por tan grande $S$ : en tamaña tarde $O 25$ escapar los ombres $M S$ : escapar $N E O P e \cdot$ fuego $M N E$ : el fuego $S O P e \mathbf{2 6}$ por atajarlo $M$ : para atajarlo $N E O P e$ : para atajar $S \cdot$ se deven $M S N E$ : se deve $O$ : devese $P$ : devense $e \mathbf{2 7}$ guiar $\Omega$ : guardar $E \bullet$ las leyes $\Omega$ : por las leyes $O \bullet$ cosa por grave que sea $N E S O$ : por grave que sea $M$ : cosa que sea $P$ : cosa sea $e \cdot$ se puede $\Omega$ : se deve $e \cdot$ bien ante razonable $a d d$. $P 28$ e sus leyes $M S N E O$ : sus leyes $P e \cdot$ por le tomar yo $M N E P e$ : porque le tome yo $O$ : para le tomar yo $S \mathbf{2 9}$ ca tornegelas $\Omega$ : tornarangelas $O \bullet$ de vençimiento $M N E$ : del vençimiento $S O P e \bullet$ famosas $\Omega$ : fermosas $P \mathbf{3 0}$ vençedoras $\Omega$ : vençedores $O \mathbf{3 1}$ acaesçe $M S N E O$ : contesçe $P e \bullet$ las riquezas $\Omega$ : riquezas $O \bullet$ de los templos om. $S \bullet$ de $\Omega$ : de la $S 32$ a los cavalleros om. $S \mathbf{3 4}$ acusador $\Omega$ : acusado $P \bullet$ acusamos $\Omega$ : acusemos $O \bullet$ que $\Omega$ : quien $e \mathbf{3 6}$ cometio $\Omega$ : acometio $P \mathbf{3 7}$ fealdad $\Omega$ : falsedad $P \mathbf{3 8}$ tomandolas $\Omega$ : como de las $P \bullet$ agravar MNe : agraviar SEOP • ca non fueron $\Omega$ : ca fueron $P \mathbf{4 0}$ aun a este $\Omega$ : a este $P \mathbf{4 2}$ se preçia $\Omega$ : paresçia $O \bullet \operatorname{como} \Omega$ : con $e \cdot$ o acusado $M S N E O$ : tu acusado $P$ : tu o acusado $e \mathbf{4 6}$ fizo que $M N$ : fizo $S E O P e \cdot$ quitemos $\Omega$ : quitamos e 47 gualardon $M E O P$ : galardon $S N e \cdot$ igualdad e justiçia $\Omega$ : igualdad de justiçia $S \mathbf{4 8}$ cavallero bivo NEPe : cavallero $M S O \bullet$ batalla $M S O$ : pelea $N E P e \mathbf{4 9}$ honrar $M N$ : vengar $S O P e$

\section{1}

1 declamaçion primera $\Omega$ : primera declamaçion $P 2$ la soga a otro $M S$ : a otro la soga $N E O$ $P e \bullet$ en que $M N E O P$ : que $S$ : con que $e \cdot$ libro de las declamaçiones ante acusanle add. $O \bullet$ acusanle $\Omega$ : acusale $P \mathbf{4}$ el caso es este om. $S \mathbf{5}$ la $^{1} \Omega$ : su $S \mathbf{6}$ por $\Omega$ : para $P \mathbf{7}$ colgandose $M O$ : colgado $S N E P e \cdot$ ende $\Omega$ : alli $S \mathbf{1 0}$ acusado $\Omega$ : acusador $O \bullet$ quexaste $\Omega$ : quexate $O \bullet$ pluguiese a Dios $M S N E$ : pluguiera a dios $O P$ : pluguiera dios $e \mathbf{1 1} \operatorname{los} \Omega$ : la $O \mathbf{1 3}$ los ... asconden om. $P 14$ quebranta el navio $M S$ : quebrantan los navios $N E O P$ : quiebran los navios $e \mathbf{1 5}$ 
cuidavas $M N E O P$ : cuidas $S e \mathbf{1 6}$ ca quita $M$ : e quita $S N E O e$ : ca tira $P \mathbf{1 8}$ ella non tiene en que le faga mal $M S e$ : non tiene en que ella le faga mal $N E P$ : non tiene en que le faga mal $O \cdot$ Gneo $M$ : Gueyo $N$ : Geneo $S O$ : Gueyno $E$ : guerrero $P$ : Quereo $e \cdot$ Pompeyo $M N$ : Pompeo $S E O-$ $P e 19$ si $\Omega$ : asi $S \cdot$ de tus fijos e muger $M N$ : de tus fijos e de tu muger $S E O P$ : e de tu muger e 20 tu $^{2}$ om. Oe • te quieres $M S$ : quiereste $N E O P e \cdot$ ca $M N E O P$ : que $S e \mathbf{2 2}$ tiro $\Omega$ : tira $O \mathbf{2 3}$ e si ... esperança $o m$. $O \bullet$ non $^{2}$ om. $E \bullet$ que $\Omega$ : e $O \mathbf{2 4}$ muchos vençidos MSNEP : muchos vençidos fueron $O$ : mucho vençidos $e \cdot \operatorname{nin}$ om. $O \mathbf{2 6}$ de una vez $M S$ : que una vez NEOP : de $e$ 27 que mas quisiese navegar $M S N E e$ : quisiese navegar $P$ : que mas navegase $O \mathbf{2 8}$ contrarias om. $O 29$ yo ove $M S N E O$ : ove yo $\mathrm{Pe} \bullet$ otra cosa $\Omega$ : otras cosas $O \bullet$ aventuras y desventuras : aventuras ssy desaventuras $M$ : desventuras $N O$ : desaventuras $S E P e \mathbf{3 0}$ cortete $\Omega$ : cortete yo $P \mathbf{3 1}$ fijos nin de tu muger $S$ : fijos $\Omega \mathbf{3 2}$ pues que $M N E O$ : pues $S:$ despues que $P e \mathbf{3 8}$ atara $N E P e$ : estava $M S O 39$-me morir $\Omega$ : memoria $E \mathbf{4 0}$ ventura $N E P O e$ : aventura $M S \cdot \operatorname{diras} M N E$ : diras tu $S$ : tu diras $P e \mathbf{4 1}$ quisieres $M S N E O$ : quieres $P e \mathbf{4 3}$ e soga la soledad om. $P \mathbf{4 4}$ soga porque era cosa $\Omega$ : cosa porque era cosa $P 45 \operatorname{cosa}$ propia $\Omega$ : propia cosa $e \cdot$ qualquier $\Omega$ : a qualquier $S \bullet$ fazer al MNPe : al fazer $S E O \mathbf{4 6}$ oteaselo $\Omega$ : miraselo $S \bullet$ callase $\Omega$ : callaselo $S$ $\mathbf{4 7}$ pero om. $S \cdot$ calidad $\Omega$ : crueldad $S \cdot$ seria $M O$ : sera $N E P$ e 48 deven $\Omega$ : deve $S \mathbf{4 9}$ deviera $\Omega$ : la deviera $E \bullet$ deve vedar $\Omega$ : deve dar $E \bullet$ nin deve om. $P \bullet \operatorname{cosas}$ e desaventuras $M$ : todas estas desventuras $N O$ : estas desaventuras $S E P$ : cosas desaventuradas $e \mathbf{5 0}$ queria $\Omega$ : que queria $S 52$ estorvada $M S O$ : estorvado $N E P e \cdot$ si non de bevir $N E O P e$ : de bevir $M S 53$ todos om. $P \bullet$ en om. $S \mathbf{5 4}$ o acusado $\Omega$ : acusado $e \mathbf{5 5}$ para $\Omega$ : por $S \cdot$ escapavas $\Omega$ : escusavas $S \mathbf{5 6}$ quebrada $M S O P e:$ quebrantada $N E$

\section{7}

2 e los mataron los enemigos post capitan $a d d$. $O 4$ en una çibdad avia una ley $M S$ : avia una ley en una çibdad $N E O P$ : avia una ley en la çibdad $e \cdot$ alguno MSNEe : ninguno OP $\mathbf{5}$ guerra $\Omega$ : mar $P \mathbf{6}$ es este $o m$. $N \bullet$ aquella $M S N E O$ : la $P e \mathbf{8}$ çerca $M N E O$ : açerca de $S$ : çerca de $P e$ 9 acusan $\Omega$ : acusavan $O \mathbf{1 0}$ çibdadanos $\Omega$ : capitanes $e \mathbf{1 2}$ eran $\Omega$ : ellos eran $S \mathbf{1 3}$ de noche om. $P e \cdot \operatorname{devia} M S O P e$ : devo NE 14 de los om. $S \bullet$ me dixere el acusador $\Omega$ : el acusador me dixiere $S \cdot$ dexavas $M S N E$ : dexamos $O P$ e 15 mas om. $O \bullet$ non post porque add. $P 16$ vinieran $M N O e$ : llegaran $N E P 17$ vinieran $^{2} \Omega$ : viniesen $e \cdot$ devia resçebir $M S$ : deviera resçebir NEOe : resçibiera ca non los devia resçebir $P 18$ el otro $\Omega$ : este otro $S \bullet \mathrm{e}^{1} \mathrm{om}$. $M \bullet$ veo $\Omega$ : vi $S 20$ fuyendo $M S N E P$ : fuyeron $O e \cdot$ curaron $\Omega$ : curando $O 21$ gran apretura $M P$ : en grand aprieto $S$ : muy grand apretura NEOe $\mathbf{2 2}$ tanto om. Pe $\mathbf{2 3}$ defenderian $\Omega$ : los defendieron $P$ $\mathbf{2 4}$ davan $\Omega$ : dava $S \mathbf{2 5}$ tovieron $M P e$ : ovieron $O$ : tovieran $N E S \bullet$ defendiendo $\Omega$ : defendieron $O \mathbf{2 6}$ yo om. $P e \cdot$ o que $\Omega$ : e que $e \mathbf{2 9}$ entrar MSNEe : entravan $P$ : entraran $O \cdot$ yo abriera $M S N E P$ e : ovieran $O \mathbf{3 1}$ dize el acusador $o m$. $N E \bullet$ destos $M S O$ : a estos $N E$ : a $P$ e $\mathbf{3 3}$ fuyendo venian $M S$ : venian fuyendo $N E P e$ : fuyeron $O \bullet$ es om. $O \bullet$ presos los ombres $S N E O P$ : ombres $M$ : prestos los ombres $e \mathbf{3 4}$ ca om. $S \cdot$ fuertes $M P$ : muy fuertes $S N E O e \mathbf{3 5}$ pedian $M N E O e$ : podian $S$ : podrian $P \bullet$ que les diesen om. $O \bullet$ diesen $M e:$ diese $S N E P 36$ diziendole $\Omega$ : diziendo $e \cdot$ capitan $M S O$ : o capitan $N E P e$

\section{2}

1 marido e muger $\Omega$ : un marido e su muger $O 4$ es este NSEPe : es esto $O:$ om. $N \bullet$ juraron $\Omega$ : jurando $O \cdot$ muriese $\Omega$ : se muriese $P \mathbf{5}$ de alla $\Omega$ : desde alla $S \mathbf{6}$ que era muerto $\Omega$ : que su marido que era muerto $O 7$ escapo $\Omega$ : sano $O \mathbf{8}$ pues $\Omega$ : pues que el $O \cdot$ por esto $\Omega$ : sobre esto $e \mathbf{9}$ contienden $\Omega$ : contiende $S$ • esta deseredaçion $\Omega$ : este deseredo $S \mathbf{1 2}$ quanta de- 
vedes $\Omega$ : quanto devedes $M \cdot$ de aquel $M:$ que aquel $S N E P e$ : aquel $O \mathbf{1 3}$ troxiese $\Omega$ : troxistes $O \cdot$ fiziese $M S N E e$ : fize $P$ : fezistes $O 14$ lo $M e: \operatorname{los} S N E O P \cdot$ quiere $N E O P e$ : queria $S$ : quieren $M 15$ non om. $P \bullet$ ser por ello $M S O e$ : por ello ser $N E$ : por eso ser $P 17$ quemavan $S N E P e$ : queman $M$ : querian quemar $O \mathbf{1 8}$ la vida $M S N E O$ : las muertes $P$ : la muerte $e \mathbf{1 9}$ moça $\Omega$ : como moça $O \bullet$ so e biva $e$ : so biva $S N E O P$ : sabina $M \bullet$ nombradas e famosas $M S$ : famosas NEOPe $\mathbf{2 0}$ por om. M21 podria bevir ... biviria $M N O P e$ : podria bevir ... biviera $E$ : podia bivir ... podria yo bivir $S \cdot$ e dezia ... el muriese om. $O 22$ deximos $M N P e$ : deziamos $S E O 23$ pues om. $M \bullet$ juramos $\Omega$ : juramosnos $E \mathbf{2 4}$ non $^{2}$ om. $O 26$ dize om. $P \bullet \operatorname{otra}$ om. $N \bullet$ contra $M S O P e$ : de $N E \mathbf{2 7}$ fazer om. e $\mathbf{3 0}$ absençia $\Omega$ : abstinençia $e \cdot$ luengamente $\Omega$ : luengo tiempo e 31 ya del $M e:$ del ya $S N E$ : ya por el $P$ : dello $O$

\section{5}

1 de la declamaçion $M S E O e$ : la declamaçion $N$ : de la clemençia $P 4$ en una ... dezia asi $M S$ : la ley dezia asi NEPe : om. $O \bullet$ a sabiendas om. $S \mathbf{5}$ fizo $\Omega$ : fiziere $S \cdot$ e el que lo fiziere $\Omega$ : e si lo fiziere $S \mathbf{6}$ monta $M S N e$ : montase $P$ : montare $O 7$ el caso es este : MEPe : el caso $N$ : om. $O \cdot$ delante $M S O e$ : ante $N E P 10$ quemose $\Omega$ : quemosele $O \mathbf{1 1}$ non mas del tanto $M$ : non mas de al tanto $N E O$ : non mas del altanto $S$ : non al mas de al tanto $P$ : el tanto $e \mathbf{1 2}$ de todo $M S N E e$ : por todo $P$ : del todo $O \mathbf{1 5}$ pregunte $M S$ : fue preguntar NEOe : fui a preguntar $P \mathbf{1 6}$ fiziera $\Omega$ : fazia $P \bullet$ estendidas $\Omega$ : tendidas $P 17$ cubrian $M S N e$ : cubria $N O P \bullet$ toda $\mathrm{om} . O \bullet$ que pues $M$ : que pues yo $S:$ pues que yo $N E e$ : pues yo $P:$ que pues que yo $O \mathbf{1 8}$ quemarle $\Omega$ : de quemarmele $S \cdot$ desvergonçada $M S N E O$ : desvengada $P e 19$ devia $M S O$ : me devia $N P e$ 20 entendio el $M N E P e$ : entendido es $S$ : entendia el $O 21$ que es razon om. e 22 algun $\Omega$ : un $P$ - sus arboles om. $S \mathbf{2 3}$ tantas om. $O 24$ montes $\Omega$ : arboles $O 26$ un $\Omega$ : una $e \mathbf{2 7}$ tu om. NEOPe $\mathbf{2 8}$ e mas graçiosa om. $P 29$ enderredor $\Omega$ : alderredor $P \bullet \operatorname{diras} \Omega$ : dirias $S \bullet$ a tu $\Omega$ : la tu $S \cdot$ que maravilla hay en esto $\Omega$ : que me maravilla es esto $e \mathbf{3 2}$ embargannos $\Omega$ : embarga$\operatorname{nos} M \bullet \operatorname{otros} \Omega$ : los $e \mathbf{2 9}$ mas $\Omega$ : mas nos $E \mathbf{3 6}$ yo om. $M \mathbf{3 8}$ resçibiera yo tanto mal MSNEP : resçibiera tanto mal $O$ : tanto mal resçibiera $e \cdot$ que om. NEPe 39 se repare $\Omega$ : que se repare $P \bullet$ el om. SNEOP 41 fazia $\Omega$ : contra $S \bullet$ cada $\Omega$ : toda $O \bullet$ en el ... en el $M S O$ : en el ... en $N$ : en ... en el $E$ : en ... en $P$ e 42 año $\Omega$ : tiempo $O \bullet$ non om. $O 43$ peçes $\Omega$ : pozos $O 44$ se navegarian $M S N E$ : se navegaran $O$ : navegarian $P$ : navegaran $e \cdot$ en otro tiempo $M O$ : otro tiempo SNEP : otros tiempos $e \cdot$ moravan pueblos $\Omega$ : morava pueblo $e \cdot$ avian asaz $M S$ : avian en ella asaz $N E$ : avia en ella asaz $O P$ : avian en ello asaz $e \mathbf{4 5}$ tienela $\Omega$ : tienenla $M \bullet$ como om. $S \cdot$ alqueria $M N E:$ om. $S$ : alcaria $O P e \mathbf{4 7}$ ya om. $P \bullet$ molles $\Omega$ : muelles e 48 tamaño es el poderio del fuego $M N E P e: \tan$ grande poderio del fuego $S:$ tamaño poderio es el poderio del fuego $O 49$ desque es començado om. e $\mathbf{5 1}$ aunque post daño trans. $O \cdot$ que post pues add. $P \mathbf{5 2}$ eres om. $e \mathbf{5 3}$ lo deve non saber MSNEO : lo non deve saber $P$ : non lo deve saber $e$ 54 que $^{1}$ om. e 55 alguno $\Omega$ : ninguno $P$ ençienda todo $\Omega$ : entienda del todo $P \mathbf{5 6} \operatorname{cosa} \Omega$ : casa $e \cdot$ partes post todas add. $P 57$ en el om. MSO 61 partes $\Omega$ : paredes $O \bullet$ podia $\Omega$ : me podia $P 62$ aprovechan $\Omega$ : aprovecha $N 63$ avian dañado $M S N O P$ : avia fecho daño $E$ : om. $e \mathbf{6 4}$ ca $M S N E$ e : que $O P$

\section{6}

$1 \mathrm{de}^{2} \Omega$ : dize de $S \mathbf{5}$ es este om. $N \cdot$ uno $\Omega$ : un ombre $e \mathbf{1 1}$ con quien $\Omega$ : que $P \mathbf{1 2}$ de las $\ldots$ e del MSNEO : de ... e de $P$ e 14 dixe $\Omega$ : yo dixe $P 15$ paresçe $\Omega$ : paresçia $e \mathbf{1 8}$ se fiziese $\Omega$ : hiziese $e 19$ los $M S N$ : lo EOPe 20 se om. $P 21$ muy om. $P$ • conglueça $M N$ : colvueça $S$ : comblueça $E O$ : combleça $P$ : cumbleça e 22 malaventurada MSNEe : mala ventura $O$ : mala $P \bullet$ 
allega $\Omega$ : llega $e \mathbf{2 3}$ dixele $\Omega$ : dixole $O \mathbf{2 4}$ loele $M N E P$ e : loavale $S O \bullet$ cometia $\Omega$ : cometio $O 25$ indiscreto $\Omega$ : discreto $P \mathbf{2 6}$ lo $^{2}$ om. NEOe 27 en onras $\Omega$ : obras $P \cdot$ mortuorios $M S N E O$ : mortuorio $P e \bullet$ las onras de ante las bodas add. $O \mathbf{2 8}$ alegres fachas $M S N O$ : alegres fechas $E$ : alegrias hechas $P e \bullet$ suelen $\Omega$ : se suelen $e \bullet$ tornaron $\Omega$ : tornan $e \mathbf{2 9}$ quemase $\Omega$ : quema $e \cdot$ que $^{2} \Omega$ : e $S \mathbf{3 0}$ finchado $\Omega$ : finchada $S \cdot$ prueva $\Omega$ : pena $P \bullet$ o juezes $M S N E O$ : o juez $P e$ - ca $M S N E O$ : que Pe 31 los om. NE 32 se $M S O P e$ : lo $N E \mathbf{3 3}$ veyendola muerta $M S N E$ e : veyendo la muerte $O P \mathbf{3 4}$ perdi $\Omega$ : perdi yo $P \bullet$ por adulterio om. $P \bullet$ e a la fija por las yervas $M S N E$ : e a la fija por yervas $O P$ : con las yervas $e \mathbf{3 7}$ contra el marido om. $O P \mathbf{3 8}$ dar yervas $\Omega$ : yervas $e \cdot \operatorname{con} \Omega$ : por $S \mathbf{4 0}$ que dize que dixo $\Omega$ : que dixo que $P \cdot$ el casamiento $M S N E e$ : de casamiento $P$ : el caso $O \mathbf{4 1}$ asañose $M N E O P$ : ensañose $S$ : ca ensañose $e \mathbf{4 2}$ salieronsele $M S O P e$ : salieronle $N$ : salieronse $E \mathbf{4 3}$ clara $\Omega$ : claramente $P \cdot$ case con el MSNEP : casa con el $O$ : con el case $e \mathbf{4 4}$ ante dicho $\Omega$ : dicho ante $e \cdot$ de su fija $\Omega$ : que habia hablado de su hija $e \mathbf{4 5}$ consideraçion $\Omega$ : contradiçion $S \cdot$ muchas vezes om. $O 46$ dize $\Omega$ : bive $E$ : viene $E$ alia manu correcto

\section{8}

1 desunt MS 5 por $\Omega$ : sobre $e \cdot$ es este $o m$. $N \bullet$ entrada $\Omega$ : entrado $P \mathbf{6}$ que resçibiesen en su çibdad $N E O$ : que resçibiesen en la çibdad $P$ : en su çibdad $e \mathbf{7}$ viejo om. $P \mathbf{8}$ conbidolo $\Omega$ : a su fijo e a el conbidolos $E$ alia manu correcto 9 fablava $\Omega$ : estava fablando $P \cdot$ matarle $E O P$ : matar $N e \mathbf{1 0}$ del $\Omega$ : que fazia $P \mathbf{1 2}$ acusan $E e$ : acusa $N O \bullet$ agora ... viejo om. $P \mathbf{1 4}$ dexan $\Omega$ : dexar $P \bullet$ al $\Omega$ : el $e \mathbf{1 5}$ pueda $N P e$ : puede $E O 17$ la om. $P e \cdot$ e uno $N E O$ : e el uno $P$ : el uno $e \mathbf{1 9}$ tope $\Omega$ : que tope $P \mathbf{2 1}$ diestras NEe : destas $P$ : discretas $O \mathbf{2 3}$ pueda $\Omega$ : puede $e \mathbf{2 4}$ acusanme agora diziendo $\Omega$ : recusanme agora $e \mathbf{2 5}$ la çibdad ante Olintho add. $P \mathbf{2 6}$ acusanme $\Omega$ : acusan $E 30$ una $\Omega$ : la $E \cdot$ o estan pocos $\Omega$ : o los que estan pocos $O 32$ partes $N E O$ : partese $P e \cdot$ vocablo ayuntamiento e bolliçio $O P$ : vocablo de ayuntamiento e bolliçio $e$ : ayuntamiento de vocablo e bolliçio $N E \mathbf{3 3}$ allega $\Omega$ : llega $P \mathbf{3 4}$ primero $\Omega$ : primeramente $P \bullet$ mas despues llegaronse $N E$ : e despues llegaronse $O$ : e despues allegaronse $P$ : despues llegaronse $e \mathbf{3 5}$ el pueblo ... fuego que om. $e \cdot$ mas mirar NEO : mirar mas $P \mathbf{3 6}$ dezides $\Omega$ : deziades $O \bullet$ se faze el ayuntamiento e bolliçio $\Omega$ : el ayuntamiento se faze $e \mathbf{3 7}$ mas ... faze om. e $\mathbf{3 9}$ quemase $N e$ : quemasen $E O P 41$ dize ... parte om. $E \bullet$ menester om. $e$ fazer $\Omega$ : de fazer $P \bullet$ ayuntamiento $e$ : llegamiento $N E O$ : allegamiento $P \mathbf{4 2}$ mucha om. $e \mathbf{4 3}$ ha $\Omega$ : han $e \bullet$ muy bien om. $e \mathbf{4 4}$ toda la $\Omega$ : una $e$

\section{TEXTO LATINO}

\section{5}

$\mathbf{6}$ accusator $M_{c} \mathbf{8}$ uix duos credens raptores fuisse $T \cdot$ alteram ... alteram : -um ... -um $M_{c} \mathbf{1 0}$ rapuisses Håk Müll 13 non : num $M_{c} 15$ uincit $T \cdot$ lucratiuam $A^{\text {a.c. }} \bullet$ uirginem $T 16$ erit mihi $T$ 17 homo ... honorem om. T

\section{2}

1 desunt $A T \cdot$ amissis manibus : truncatus $\alpha \mathbf{5}$ rapuisse om. $P_{c} 7$ contradicit $P_{c}$ contradicuntur $\alpha \mathbf{9}$ possumus $\alpha \beta \lambda v$ : possum $M_{c} P_{c} \rho \mathbf{1 7}$ dii $\alpha$ : Elii Håk Müll 


\section{9}

$\mathbf{6}$ heres $A T$ : erus Håk Müll $\mathbf{9}$ malui MPS $\mu A T$ : maluit Müll $\beta v$ : maluit <enim> $\boldsymbol{\alpha} \mathbf{1 0}$ uincitur : inuenitur $A 11$ furiosus Håk Müll AT • seruum Håk Müll 13 seruum $\alpha T$ : serua natum Håk Müll : seruum natum $v$ : seruo natum $M P S \beta \mu \bullet$ indice Håk Müll T : iudice $\alpha \mu \bullet$ liberorum cum Müll : liberorumque $\alpha \mu A T 14$ Tarquino : Tarquiniis Håk Müll : Tarquinii $\alpha \mu A T 15$ occidere om. T17 minaris $A 24$ ei $\mu$ : om. $\alpha A T \bullet$ agatur $T 25$ uiui $\alpha \beta \mu$ : serui uiuorum Håk Müll • imperia neglexerint $T \mathbf{2 6}$ fur ei praeferatur non $\alpha T$ : furcifer tu non Håk Müll

\section{4}

$\mathbf{3}<$ iam $>$ esset $A T \cdot$ ciuitatem $A \bullet$ amissis armis $A T \mathbf{8}$ uere : iam $A T \bullet$ illuc $\gamma \mathbf{1 1}$ sit $\alpha \mathbf{1 2}$ melius <enim $>T$ pro ipso $A T \cdot$ factum $\alpha A T \cdot$ notoria $T \cdot$ arma iterum $A T 13$ populumque $\alpha \mathbf{1 6}$ post crimine deest $A \mathbf{1 8}$ reposuit $T \mathbf{2 2}$ nos esse $T \mathbf{2 3}$ orauimus $T^{\text {a.c. }}$

\section{1}

1 deest $A 4$ illi praecidit $T \mathbf{9}$ putas $T \mathbf{1 0}$ Fortuna de suis $T \mathbf{1 1}$ tutius est illam : opus est eam $T \bullet$ quam cum : tum qua $T \mathbf{1 2}$ Thesalia $T \cdot$ mortem tuorum om. Håk Müll 14 omnibus $T \mathbf{1 5}$ appeteret $T \mathbf{1 6}$ enatasti $T \mathbf{1 8}$ illam $T^{\text {a.c. }} \cdot$ uisus es $T \cdot$ habuisse in margine $T \mathbf{2 1}$ tollat $\beta \pi$ : tot ille Håk Müll : tollit $T S_{c}$ : tulit $\alpha \mathbf{2 3}$ mihi om. T 28 fides est $T \mathbf{2 9}$ facta Håk Müll

\section{7}

3 non liceat $P_{c} S_{c} \alpha \beta v \pi$ : ne liceat Håk Müll 5 reus : reuersus $\alpha \mathbf{8}$ interdiu : interdum $\alpha$ : in die $\pi 17$ illis trecentis $\alpha \pi$ : trecentis Håk Müll $\bullet$ agi possent $v \pi$ : argui posset Håk Müll : agi possit $M_{c} S_{c} \alpha \beta 19$ certe hoc $v$ : certe Håk Müll : et hoc facere certe $\beta$ hoc certe $B s$

\section{2}

9 maritorum $<$ suorum $>T \mathbf{1 0}$ contemptiones $P_{c} 12$ iuramentum $P_{c} \bullet$ diducerentur ... morte om. $T$

\section{5}

1 exausta $T \mathbf{3}<$ in $>$ quadruplum $T \bullet$ soluat : puniatur $\pi T \bullet<$ in $>\operatorname{simplum} T \bullet$ nesciens $T \mathbf{4}$ sibi om. $T \mathbf{8}$ primo om. $\pi T \cdot$ imploraui : exploraui $T \cdot$ ramis om. $\alpha \mathbf{1 0}$ imprudentiae $\pi \mathbf{1 1}$ expugnetur $S_{c} \alpha \beta v \pi$ : expellatur Bs Håk Müll : expellantur $M_{c} P_{c} \bullet$ inter me $T$ : inter te Fb Håk Müll 13 laetius $\alpha \pi T$ : lautius Håk Müll : latius $T^{\text {a.c. }} \mathbf{1 6}$ prospectus : prospectis $\alpha \pi \cdot$ nobis om. $\alpha \mathbf{1 7}$ excitati : erecti $\alpha \pi$ : eiecti $T 19$ nos : uos $\alpha \pi 20$ iniquum : inimicum $\alpha$ iniquo $\pi 22$ omne : omnis $\pi 23$ agunt in summis $S_{c} \alpha \beta v \pi T$ : ut sint in summis Gz Müll : in summis Håk $M_{c} P_{c}$ : alunt Frob 24 aurata $T 25$ nunc uillici $\alpha v \pi T$ : uillici Håk Müll $M_{c} P_{c} S_{c} 28$ etiamsi : etiam $P_{c}^{c}$ : etsi $\alpha \pi \cdot$ uoluisti : noluisti $M_{c} P_{c} v 29$ inprudentia : prudentia $\alpha 30$ incendisse : incedisse $\alpha \cdot$ si unum tignum post ex parte trans. Herv Håk Müll 32 se om. $\pi 34$ mihi om. $P_{c} \bullet$ per quod : pro quo $\pi 36$ illi om. $\alpha$

\section{6}

3 beneficii fit $\alpha \mathbf{5}$ cruditatis Håk Müll 9 teneo ${ }^{2}$... nubat om. T 11 iudices $\alpha \mathbf{1 3}$ adulterium $M_{c} \alpha \beta v T$ : adulterium ueneficii $H a ̊ k$ : ueneficium adulterii Müll $\mathbf{1 7}$ proferunt $T \cdot$ tumens : canens $T^{\text {a.c. }} \mathbf{1 8}$ 
ad ... conueniunt om. $T \cdot$ fata $M_{c} P_{c} S_{c} \alpha \beta$ : facta Håk Müll 21 ueneno $\alpha T$ : ueneficio Håk Müll $\mathbf{2 3}$ grauissima : grauia $\alpha T \mathbf{2 5}$ pater $v$ Müll : om. Håk $\mathbf{2 6}$ dolor $\alpha T \cdot$ considerat $\alpha T$

\section{8}

3 capitalis $S_{c} \alpha \beta \mu v T$ : capital Håk Müll $M_{c} \mathbf{5}$ filio $\alpha \mathbf{1 0}$ misero : merito $\mu$ : miseros $A T^{\text {a.c. }} \cdot$ est om. $A \cdot$ imperari $M_{c} \beta \mu v$ : imperare $P_{c} \alpha T A^{c \text { a.c }} 12$ alicuius raptoris $T 18$ quotiens ${ }^{2}$ : totiens $\alpha 19$ afflixit $T^{\text {a.c. }} \mathbf{2 0}$ ubi $M S \alpha \mu v T$ : ubi est Müll : est $\boldsymbol{\beta} \mathbf{2 1}<$ in> initio $T \mathbf{2 4}$ sed ... est om. AT 25 populo $T \cdot$ potuit $T$ 